Article

\title{
Synthesis of New Brassinosteroid 24-Norcholane Type Analogs Conjugated in C-3 with Benzoate Groups
}

\author{
Karoll Ferrer $^{1,2,3}{ }^{\mathbb{D}}$, Katy Díaz ${ }^{1} \mathbb{D}$, Miroslav Kvasnica ${ }^{2,3, * \mathbb{D}}$, Andrés F. Olea ${ }^{4} \mathbb{D}$, Mauricio Cuellar ${ }^{5}$ \\ and Luis Espinoza $1, *$ (D)
}

1 Departamento de Química, Universidad Técnica Federico Santa María, Avenida España 1680, Valparaíso 2340000, Chile; karoll.ferrer.14@sansano.usm.cl (K.F.); katy.diaz@usm.cl (K.D.)

2 Laboratory of Growth Regulators, Institute of Experimental Botany, The Czech Academy of Sciences, Palacký University, Šlechtitelů 27, 78371 Olomouc, Czech Republic

3 Department of Experimental Biology, Faculty of Science, Palacký University, Šlechtitelů 27, 78371 Olomouc, Czech Republic

4 Instituto de Ciencias Químicas Aplicadas, Facultad de Ingeniería, Universidad Autónoma de Chile, El Llano Subercaseaux 2801, Santiago 8900000, Chile; andres.olea@uautonoma.cl

5 Facultad de Farmacia, Escuela de Química y Farmacia, Universidad de Valparaíso, Av. Gran Bretaña 1093, Valparaíso 2340000, Chile; mauricio.cuellar@uv.cl

* Correspondence: kvasnica@ueb.cas.cz (M.K.); luis.espinozac@usm.cl (L.E.); Tel.: +42-07-31664627 (M.K.); $+56-32-2654425$ (L.E.)

Citation: Ferrer, K.; Díaz, K.; Kvasnica, M.; Olea, A.F.; Cuellar, M.; Espinoza, L. Synthesis of New Brassinosteroid 24-Norcholane Type Analogs Conjugated in C-3 with Benzoate Groups. Molecules 2021, 26, 1173. https://doi.org/10.3390/ molecules26041173

Academic Editor: Silvia Socoro

Received: 25 January 2021

Accepted: 18 February 2021

Published: 22 February 2021

Publisher's Note: MDPI stays neutral with regard to jurisdictional claims in published maps and institutional affiliations.

Copyright: (c) 2021 by the authors. Licensee MDPI, Basel, Switzerland. This article is an open access article distributed under the terms and conditions of the Creative Commons Attribution (CC BY) license (https:// creativecommons.org/licenses/by/ $4.0 /)$.

\begin{abstract}
The metabolism of brassinosteroid leads to structural modifications in the ring skeleton or the side alkyl chain. The esterification and glycosylation at C-3 are the most common metabolic pathways, and it has been suggested that conjugate brassinosteroids are less active or inactive. In this way, plants regulate the content of active brassinosteroids. In this work, the synthesis of brassinosteroid 24-norcholane type analogs conjugated at C-3 with benzoate groups, carrying electron donor and electron attractant substituents on the aromatic ring, is described. Additionally, their growth-promoting activities were evaluated using the Rice Lamina Inclination Test (RLIT) and compared with that exhibited by brassinolide (used as positive control) and non-conjugated analogs. The results indicate that at the lowest tested concentrations $\left(10^{-8}-10^{-7} \mathrm{M}\right)$, all analogs conjugated at C-3 exhibit similar or higher activities than brassinolide, and the diasteroisomers with $S$ configuration at $\mathrm{C}-22$ are the more active ones. Increasing concentration $\left(10^{-6} \mathrm{M}\right)$ reduces the biological activities of analogs as compared to brassinolide.
\end{abstract}

Keywords: synthesis; brassinosteroids; analogs; 24-norcholane; benzoate esters; Rice Lamina Inclination Test; conjugated in C-3

\section{Introduction}

Brassinosteroids (BRs) are an important group of polyhydroxylated sterol plant growth regulators in multiple developmental processes, at nanomolar to micromolar concentration, including cell division, cell elongation, vascular differentiation, reproductive development, and modulation of gene expression [1]. BRs also influence various other developmental processes such as the germination of seeds, rhizogenesis, flowering, senescence, abscission, and maturation. They also confer resistance to plants against various abiotic and biotic stresses [2-5].

Since the discovery of brassinolide (1) (Figure 1) [6], 70 BRs, among them 65 unconjugated (free) and 5 conjugated BRs, have been isolated from 60 plant species including 51 angiosperms (12 monocotyledons and 39 dicotyledons), 6 gymnosperms, 1 pteridophyte (Equisetum arvense), 1 bryophyte (Marchantia polymorpha), and chlorophyte, the alga (Hydrodictyon reticulatum). Thus, BRs are widely distributed in the plant kingdom, including higher and lower plants [7]. 


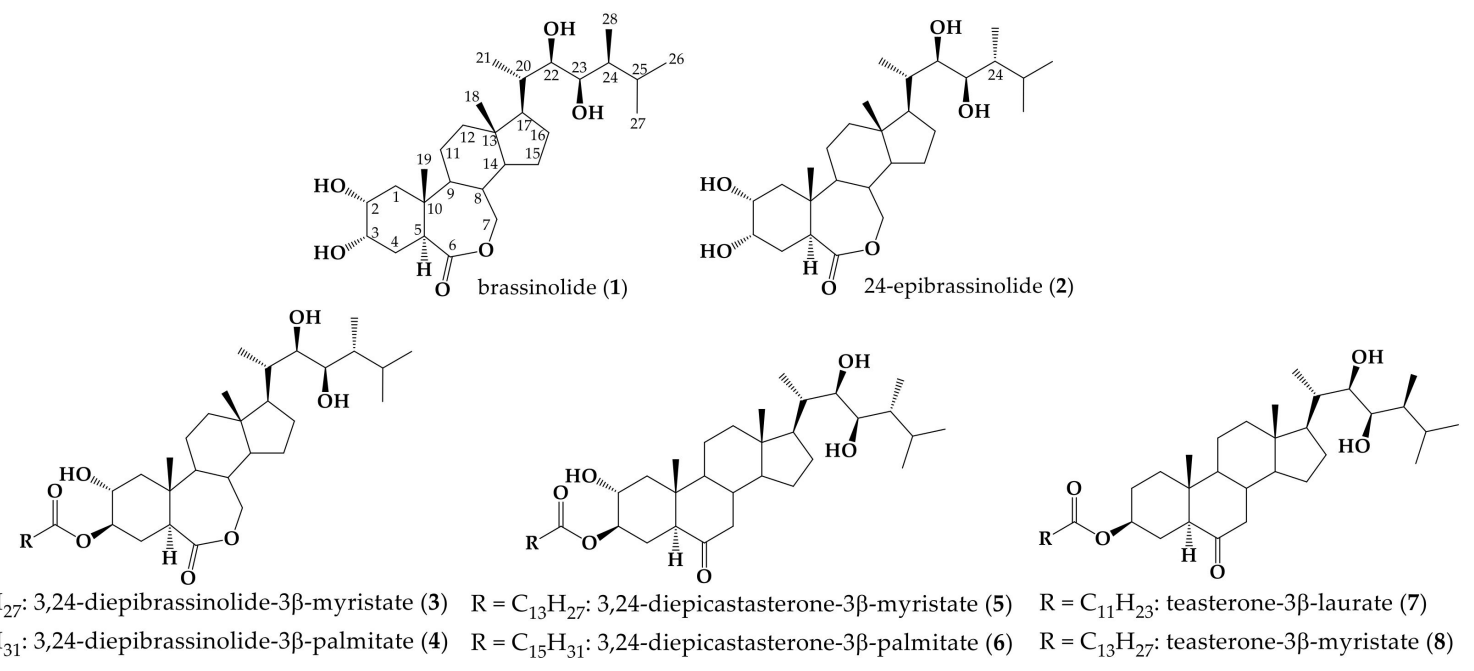

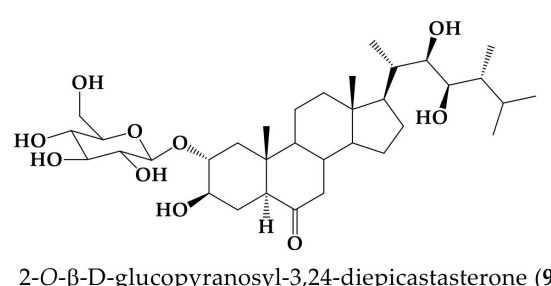

2-O- $\beta$-D-glucopyranosyl-3,24-diepicastasterone (9)

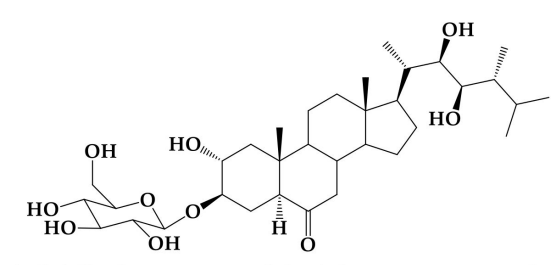

3-O- $\beta$-D-glucopyranosyl-3,24-diepicastasterone (10)

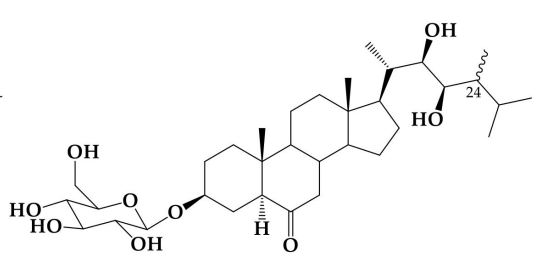

C-24 (R): $3-O-\beta$-D-glucopyranosylteasterone (11) C-24 (S): 3-O- $\beta$-D-glucopyranosylteasterone (12)

Figure 1. Structure of natural occurring brassinolide (1), 24-epibrasinolide (2), metabolites conjugated in C-3 formed by esterification (compounds 3-8), and metabolites conjugated in C-2 and C-3 formed by glycosylation (compounds 9-12).

On the other hand, a study of the miscellaneous pathways of BRs metabolism in plants reported the existence of around 19 conjugated metabolites in positions C-2, C-3, C-23, C-25, or C-26 [8]. Eight out of nineteen correspond to conjugates formed by esterification in C-3 [9-14]. The other eleven conjugated metabolites are formed by glycosylation at C-2, C-3, C-23, C-25, or C-26 [8,13-20]. Some examples of these structures are shown in Figure 1. It seems that conjugated compounds are used by plants to store inactive BRs that can be converted to active forms by de-conjugation reactions. Additionally, the natural conjugates 3, 4 (Figure 1) were synthesized from 24-epibrassinolide (2) [21].

On the other hand, a series of C-3 esterified derivatives of 24-epibrassinolide (13-15) and synthetic BRs analogs (16-19) (Figure 2) have been reported [21,22].

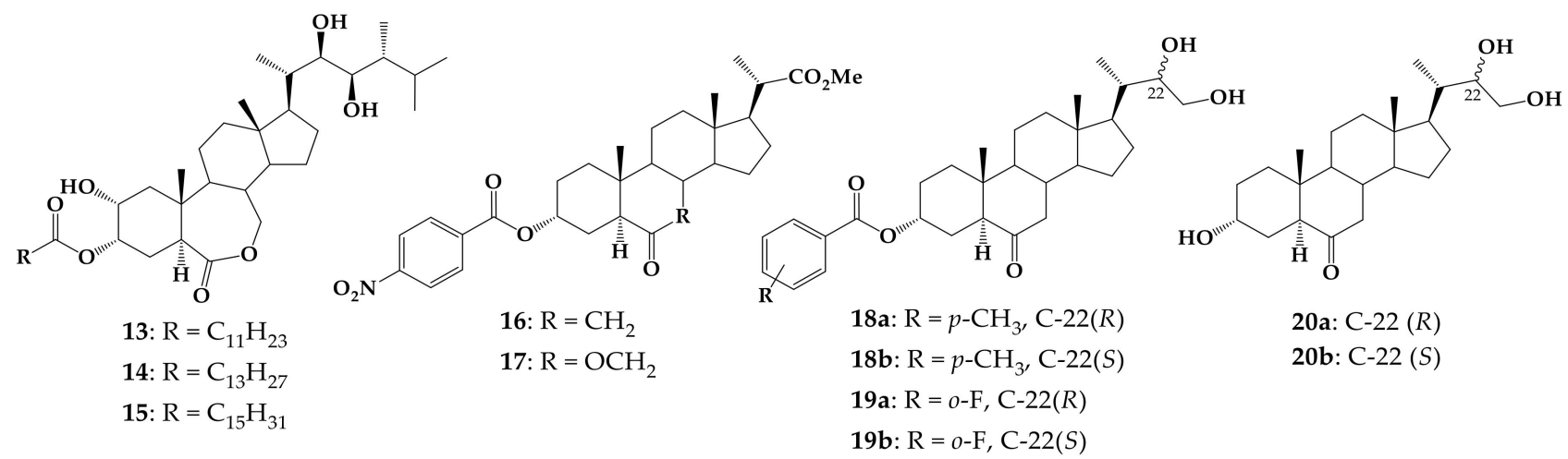

Figure 2. Structure of synthetic brassinosteroids (BRs) analogs conjugated in C-3 (compounds 13-19b) and free synthetic analogs 20a and 20b.

However, biological evaluations in the Bean Second-Internode Bioassay (BSIB) for compounds 16 and 17 indicated that these analogs are less active than 24-epibrassinolide [22]. These results are in line with previously established structure-activity relationships ob- 
tained for natural BRs. These structure-activity relationship (SAR) studies have been made using BSIB and the Rice Lamina Inclination Test (RLIT) [23-25], and their main goal is to define general structural requirements for the growth-promoting activity of BRs [24,26-29]. These results have been used to guide the synthesis of BRs analogs with a variety of structural modifications but keeping those considered essential for biological activity.

Several studies have proved that synthetic BRs analogs with significant structural changes and different substituents, both in the ring and the alkyl chain, can induce similar or even higher biological effects in plants as compared to natural BRs [30-36]. Some recent reviews of the growth-promoting activity of BRs and their analogs have established novel structural requirements for the existence of biological activity [23,37-39]. For example, it has been shown that methyl ethers at C-3 are more active than $\mathbf{1}$ in the RLIT [40], whereas benzoate esters in the $\mathrm{C}-3$ position were found to be less active than 24-epibrassinolide in the BSIB test [22].

In a previous in silico study, we have assessed the effect on activity of different groups attached to position C-3 of BRs analogs. The results suggest that bulky groups reduce the activity, whereas functionalization with electronegative and hydrophobic groups would increase it [29]. Thus, in this work, we present the synthesis of four new BR 24-norcholane type analogs conjugated with benzoate groups in C-3 (Figure 2, compounds 18a, 18b, 19a, and $19 b$ ). The aromatic ring of the benzoate group contains electron-donor and electronwithdrawing substituents. Their growth-promoting activities were evaluated using RLIT, and the results were compared with those reported for other structurally similar analogs (Figure 2, compounds 20a and 20b) [38,41,42].

The synthesis and evaluation of biological activity of these BRs analogs, conjugated in C-3 with benzylic esters, are studied either to get new active molecules or to elucidate if esterification could be a metabolic path for exogenous BRs.

\section{Results and Discussion}

\subsection{Chemistry}

To obtain the new BR analogs conjugated in C-3 (18a, 18b, 19a, and 19b, Figure 2), the synthetic strategy shown in Scheme 1 was developed. The synthesis of the key intermediate alkene $\mathbf{2 8}$ has been previously reported [43], but herein, we have introduced some modifications in the synthesis steps to increase the yields of reactions. In addition, more clear spectroscopic evidence $\left({ }^{1} \mathrm{H}\right.$ - and $\left.{ }^{13} \mathrm{C}-\mathrm{NMR}\right)$ is provided [43-45].

The standard acetylation $\left(\mathrm{Ac}_{2} \mathrm{O} / \mathrm{N}, \mathrm{N}\right.$-dimethylaminopyridine(DMAP) $\left./ \mathrm{CH}_{2} \mathrm{Cl}_{2}\right)$ of hyodeoxycholic acid (21) leads to known diacetylated derivative (22) in 91.1\% yield (ref. $80 \%$ yield, [44,45]). In the ${ }^{1} \mathrm{H}-\mathrm{NMR}$ spectrum of compound 22 (Figure S1, Supplementary Materials), the protons of both acetate groups appear at $\delta_{\mathrm{H}}=2.02 \mathrm{ppm}\left(3 \mathrm{H}, \mathrm{s}, \mathrm{CH}_{3} \mathrm{CO}_{2}-\mathrm{C} 6\right)$ and $1.99 \mathrm{ppm}\left(3 \mathrm{H}, \mathrm{s}, \mathrm{CH}_{3} \mathrm{CO}_{2}-\mathrm{C} 3\right)[44,45]$. While in the ${ }^{13} \mathrm{C}-\mathrm{NMR}$ spectrum (Figure S1, Supplementary Materials), the observed signals at $\delta_{\mathrm{C}}=170.56 \mathrm{ppm}\left(\mathrm{CH}_{3} \mathrm{CO}_{2}-\mathrm{C} 6\right), 170.52$ ppm $\left(\mathrm{CH}_{3} \underline{C O}_{2}-\mathrm{C} 3\right), 21.36$ ppm $\left(\mathrm{CH}_{3} \mathrm{CO}_{2}-\mathrm{C} 6\right)$, and $21.32 \mathrm{ppm}\left(\mathrm{CH}_{3} \mathrm{CO}_{2}-\mathrm{C} 3\right)$ confirm the presence of both acetate groups.

Oxidative decarboxylation of the side chain of compound 22, with the $\mathrm{PhI}(\mathrm{OAc})_{2} /$ $\mathrm{Cu}(\mathrm{OAc})_{2}$ system [44,45], leads to olefin 23 in 99.6\% yield (yield data were not reported by other authors). In the ${ }^{1} \mathrm{H}-\mathrm{NMR}$ of compound 23 (Figure S2, Supplementary Materials), the protons $\mathrm{H}-22, \mathrm{H}_{\text {trans }}-23$, and $\mathrm{H}_{\text {cis }}-23$ appear at $\delta_{\mathrm{H}}=5.65 \mathrm{ppm}(\mathrm{ddd}, J=17.1,10.2$ and $8.4 \mathrm{~Hz}), 4.90 \mathrm{ppm}(\mathrm{dd}, J=17.1$ and $2.0 \mathrm{~Hz}$ ), and $4.81 \mathrm{ppm}(\mathrm{dd}, J=10.2$ and $2.0 \mathrm{~Hz})$, respectively [44,45]. Meanwhile, in the ${ }^{13} \mathrm{C}-\mathrm{NMR}$ (Figure S2, Supplementary Materials), the carbons $C-22$ and $C-23$ appear at $\delta_{C}=145.06$ and $111.69 \mathrm{ppm}$, respectively. These signals confirm the presence of terminal alkene. 


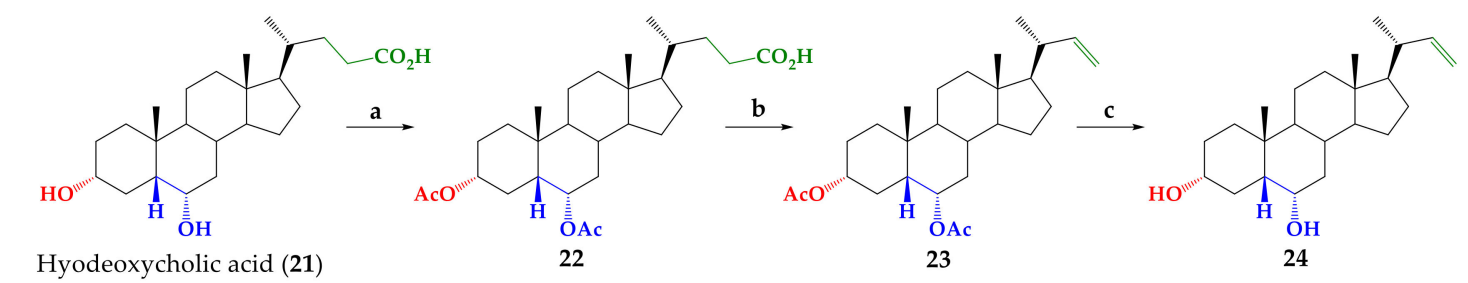

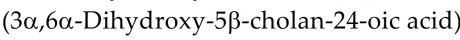<smiles>C=CC(C)C1CCC2C3CC(=O)[C@]4(C)CC(O)CCC4(C)C3CC[C@@]12C</smiles>

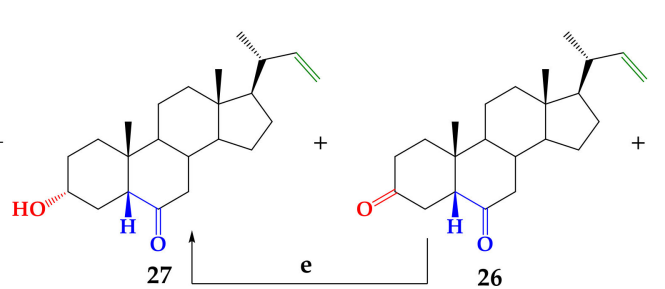<smiles>C=CC(C)C1CCC2C3CC(O)C4(C)CC(=O)CCC4(C)C3CCC12C</smiles>

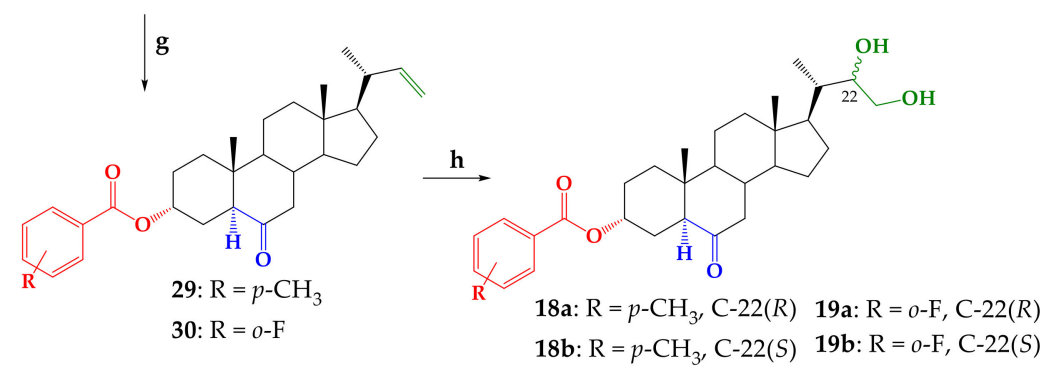

Scheme 1. Synthesis of hyodeoxycholic acid derivatives 22-30 and C-3 conjugated brassinosteroid analogues 18a, 18b, 19a, and 19b. Reagents and conditions: (a) $\mathrm{Ac}_{2} \mathrm{O} / \mathrm{DMAP}, \mathrm{CH}_{2} \mathrm{Cl}_{2}, \mathrm{rt}, 48 \mathrm{~h}, 91.1 \%$ yield; (b) $\mathrm{PhI}(\mathrm{OAc})_{2} / \mathrm{Cu}(\mathrm{OAc})_{2}, \mathrm{C}_{6} \mathrm{H}_{6}, \mathrm{reflux} 5 \mathrm{~h}$, $99.6 \%$ yield; (c) $\mathrm{K}_{2} \mathrm{CO}_{3}\left(15 \% \mathrm{p} / v, \mathrm{H}_{2} \mathrm{O}\right) /\left(\mathrm{CH}_{3}\right)_{2} \mathrm{CO} / \mathrm{CH}_{3} \mathrm{OH}$, reflux, $7 \mathrm{~h}, 97.1 \%$ yield; (d) $\mathrm{PCC} / \mathrm{CH}_{2} \mathrm{Cl}_{2}, \mathrm{rt}, 48 \mathrm{~h}$, Column Chromatography (C.C.) separation, 25 (2.4\% yield), 26 (19.1\% yield), and 27 (40.2\% yield); (e) $\mathrm{NaBH}_{4} / \mathrm{MeOH}, 0-5{ }^{\circ} \mathrm{C}, 1 \mathrm{~h}, 76.3 \%$ yield; (f) $\mathrm{HCl} / \mathrm{CH}_{3} \mathrm{OH} 2.5 \%$ v $/ v$, rt, $48 \mathrm{~h}, 74.8 \%$ yield; (g) $p-\mathrm{CH}_{3} \mathrm{C}_{6} \mathrm{H}_{4} \mathrm{COCl}$ or $o-\mathrm{FC}_{6} \mathrm{H}_{4} \mathrm{COCl} / \mathrm{DMAP} / \mathrm{CH}_{2} \mathrm{Cl} 2, \mathrm{rt}, 2 \mathrm{~h}, 29$ (87.9\% yield), $3 \mathrm{~h}, 30$ (56.0\% yield); (h) Dihydroquinidine-Chlorobenzoate(DHQD-CLB) $/ \mathrm{CH}_{3} \mathrm{SO}_{2} \mathrm{NH}_{2}, \mathrm{~K}_{2} \mathrm{CO}_{3} / \mathrm{K}_{3}[\mathrm{Fe}(\mathrm{CN}) 6]$, $\mathrm{OsO}_{4} /\left(\mathrm{CH}_{3}\right)_{3} \mathrm{COH} / \mathrm{H}_{2} \mathrm{O}, \mathrm{rt}, 5 \mathrm{~h}, \mathbf{1 8 a} / \mathbf{1 8 b}(1.0: 1.0), 91.6 \%$ yield; 19a/19b (1.0:1.0), 80.8\% yield.

The saponification of diacetate 23 with the system $\mathrm{K}_{2} \mathrm{CO}_{3} /$ acetone/methanol/reflux leads to diol 24 in 97.1\% yield (ref. 98\% yield, [43]). Although compound 24 was previously reported, no NMR spectroscopic data were reported [43,45]. So, the observed signals in the ${ }^{1} \mathrm{H}-\mathrm{NMR}$ spectrum (Figure S3, Supplementary Materials) at $\delta_{\mathrm{H}}=4.02-3.96 \mathrm{ppm}(1 \mathrm{H}, \mathrm{m})$ and 3.48-3.42 ppm $(1 \mathrm{H}, \mathrm{m})$ were assigned to carbinolic hydrogens $\mathrm{H}-6$ and $\mathrm{H}-3$, respectively (Table 1). While in the ${ }^{13} \mathrm{C}-\mathrm{NMR}$ (Figure S3, Supplementary Materials), the carbons C-6 and $C-3$ appear at $\delta_{C}=67.63$ and 71.72 ppm, respectively (Table 1 ). The assignments for the H-6 and H-3 signals were confirmed by the 2D HSQC spectrum of compound 24.

Table 1. Differences in ${ }^{1} \mathrm{H}-$ and ${ }^{13} \mathrm{C}-\mathrm{NMR}$ chemical shifts for $\mathrm{H}-3, \mathrm{H}-6, \mathrm{C}-3$, and C-6 observed for compounds $24-27$.

\begin{tabular}{ccccc}
\hline Compound & H-3 $\left(\boldsymbol{\delta}_{\mathbf{H}} \mathbf{p p m}\right)$ & $\mathbf{H}-6\left(\boldsymbol{\delta}_{\mathbf{H}} \mathbf{p p m}\right)$ & $\mathbf{C}-\mathbf{3}\left(\delta_{\mathbf{C}} \mathbf{p p m}\right)$ & $\mathbf{C}-6\left(\delta_{\mathbf{C}} \mathbf{p p m}\right)$ \\
\hline 24 & $3.48-3.42$ & $4.02-3.96$ & 71.72 & 67.63 \\
25 & - & $4.15-4.10$ & 212.63 & 67.73 \\
26 & - & - & 208.65 & 210.82 \\
27 & $3.70-3.62$ & - & 70.18 & 213.89 \\
\hline
\end{tabular}

The subsequent oxidation of compound 24 with the $\mathrm{PCC} / \mathrm{CH}_{2} \mathrm{Cl}_{2}$ system produces a mixture of three oxidation products (Scheme 1), which were efficiently separated by flash chromatographic column. So, the least polar product was identified as diketone 26 (19.1\% yield), a product of intermediate polarity identified as monoketone $25(2.4 \%$ yield), and the most polar product identified as the desired monoketone 27 (40.2\% yield). Diketone 26 was previously obtained by the oxidation of glycol with Jones reagent in 
95\% yield [45]. Meanwhile, diketone 26 and monoketone 27 were obtained by oxidation with the PDC $/ \mathrm{CH}_{2} \mathrm{Cl}_{2}$ system, with $21 \%$ and $61.7 \%$ yields, respectively [43]. The IR and ${ }^{1} \mathrm{H}-\mathrm{NMR}$ spectroscopic data for compounds $\mathbf{2 6}$ and 27 were consistent with those reported (Figures S5 and S6, Supplementary Materials) [43,45]. However, none of these previous works reported obtaining monoketone 25 . In the ${ }^{1} \mathrm{H}-\mathrm{NMR}$ spectrum of this compound (Figure S4, Supplementary Materials), the observed signal at $\delta_{\mathrm{H}}=4.15-4.10 \mathrm{ppm}(1 \mathrm{H}, \mathrm{m})$ was assigned to carbinolic hydrogen $\mathrm{H}-6$, whereas in the ${ }^{13} \mathrm{C}-\mathrm{NMR}$ spectrum (Figure S4, Supplementary Materials), the observed signal at $\delta_{C}=67.73 \mathrm{ppm}$ corresponds to C-6.

Table 1 shows the differences detected for the main signals observed in the ${ }^{1} \mathrm{H}$ - and ${ }^{13} \mathrm{C}-\mathrm{NMR}$ spectra of compounds 24 to 27 . All this information was confirmed by the 2D HSQC correlation spectra of compounds 25-27.

Diketone 26 was conveniently converted to the desired monoketone 27 by selective reduction with $\mathrm{NaBH}_{4} / \mathrm{MeOH}$ [43] at low temperature $\left(0-5{ }^{\circ} \mathrm{C}\right)$ with $76.3 \%$ yield (step e, Scheme 1). The spectroscopic data of this compound and 27, which was obtained by direct oxidation from 24 (step d, Scheme 1), were identical.

Then, compound 27 was easily isomerized under acid condition $(2.5 \% v / v \mathrm{HCl} / \mathrm{MeOH})$ to give the derivative 28 possessing $5 \alpha$-cholestan-6-one skeleton (74.8\% yield) [43,44,46-49]. The IR, ${ }^{1} \mathrm{H}$ - and ${ }^{13} \mathrm{C}-\mathrm{NMR}$ spectroscopic data registered for compound 28 were consistent with those reported (Figure S7, Supplementary Materials) [43,46].

The C-3 benzoylation reactions of $\mathbf{2 8}$ were carried out according to the methodology reported for other steroidal nuclei [41,50,51]. So, treatment of $\mathbf{2 8}$ with 4-methylbenzoyl chloride/DMAP in $\mathrm{CH}_{2} \mathrm{Cl}_{2}$ and pyridine led to 4-metylbenzoate derivative 29 with $87.9 \%$. Similarly, the reaction of $\mathbf{2 8}$ with 2-fluorobenzoyl chloride led to 2-fluorobenzoate derivative 30 with $56.0 \%$. The structures of both derivatives were mainly characterized by ${ }^{1} \mathrm{H}$ and ${ }^{13} \mathrm{C}$ spectroscopy. For derivative 29, the presence of aromatic signals at $\delta_{\mathrm{H}}=8.00 \mathrm{ppm}$ $(2 \mathrm{H}, \mathrm{d}, J=9.0 \mathrm{~Hz})$ and $6.93 \mathrm{ppm}(2 \mathrm{H}, \mathrm{d}, J=9.0 \mathrm{~Hz})$ were assigned to the hydrogens HAr- $2^{\prime}$ and HAr-3', respectively, whereas the signals appearing at $\delta_{\mathrm{C}}=163.36,131.58,123.35$, and $113.70 \mathrm{ppm}$ were assigned to the aromatic carbons $C 4^{\prime}, \mathrm{C} 2^{\prime} / \mathrm{C}^{\prime}, \mathrm{C} 1^{\prime}$, and $\mathrm{C} 3^{\prime} / \mathrm{C}^{\prime}$ (Figure S8, Supplementary Materials). For derivative 30, the presence of the aromatic signals at $\delta_{\mathrm{H}}=7.92 \mathrm{ppm}(1 \mathrm{H}, \mathrm{td}, J=7.6$ and $1.8 \mathrm{~Hz}) ; 7.54-7.48 \mathrm{ppm}(1 \mathrm{H}, \mathrm{m}) ; 7.21 \mathrm{ppm}(1 \mathrm{H}$, $\mathrm{td}, J=7.6$ and $1.2 \mathrm{~Hz})$, and $7.13 \mathrm{ppm}(1 \mathrm{H}, \mathrm{ddd}, J=10.7,7.6$ and $0.9 \mathrm{~Hz})$ were assigned to the hydrogens HAr-6 ${ }^{\prime}$, HAr- $4^{\prime}$, HAr-3', and HAr-5', respectively (Figure S9, Supplementary Materials). In the ${ }^{13} \mathrm{C}-\mathrm{NMR}$ spectrum (Figure S9, Supplementary Materials), the observed signals at $\delta_{\mathrm{C}}=161.92 \mathrm{ppm}\left(\mathrm{d},{ }^{1} J_{\mathrm{CF}}=259.1 \mathrm{~Hz}\right) ; 134.44 \mathrm{ppm}\left(\mathrm{d},{ }^{3} J_{\mathrm{CF}}=8.4 \mathrm{~Hz}\right) ; 132.32 \mathrm{ppm}$ $\left(\mathrm{d},{ }^{3} J_{\mathrm{CF}}=0.9 \mathrm{~Hz}\right) ; 124.11 \mathrm{ppm}\left(\mathrm{d},{ }^{4} J_{\mathrm{CF}}=3.6 \mathrm{~Hz}\right) ; 119.38\left(\mathrm{~d},{ }^{2} J_{\mathrm{CF}}=9.6 \mathrm{~Hz}\right) ;$ and $117.05(\mathrm{~d}$, ${ }^{2} J_{\mathrm{CF}}=21.6 \mathrm{~Hz}$ ) were assigned to the aromatic carbons $\mathrm{C2}^{\prime}, \mathrm{C} 4^{\prime}, \mathrm{C} 6^{\prime}, \mathrm{C} 5^{\prime}, \mathrm{C} 1^{\prime}$, and $\mathrm{C}^{\prime}$, respectively (Figure 3).

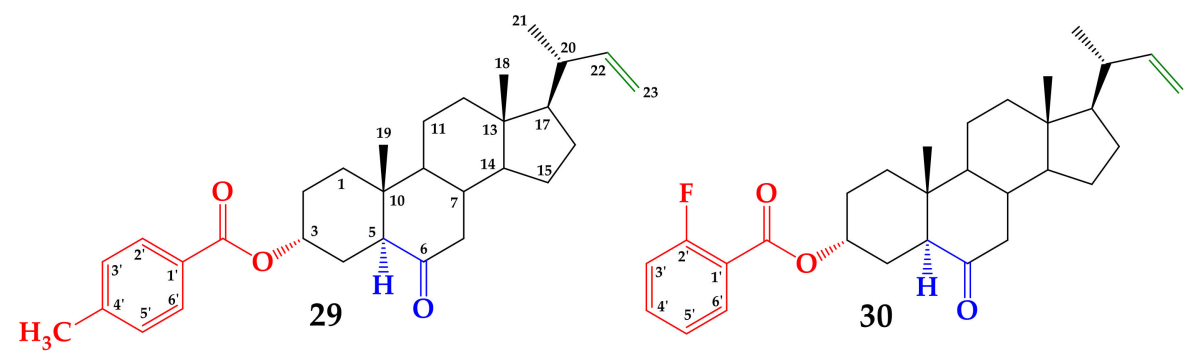

Figure 3. Structures of derivatives 29 and 30 and numbering of aromatic carbon atoms used in this study.

Recently, the synthesis of glycols C22/C23 in steroids with the shortest side chain of 24-nor-5 $\alpha$-cholane type by a Sharpless dihydroxylation reaction has been reported [42]. The results showed that this type of hydroxylation leads to a mixture of C-22 glycols $(R / S)$ with an approximate 1:1 ratio of both diastereomers [42]. Thus, both olefins 29 and 30 were dihydroxylated following this method and using dihydroquinidine $p$-chlorobenzoate 
(DHQD-CLB) as a chiral ligand (Scheme 1) [32,42]. The Sharpless dihydroxylation of derivative 29 produced the 18a/18b diastereoisomer mixture with a total $91.6 \%$ yield. The diastereomeric ratio of each glycol in the mixture can be established by the integration of ${ }^{1} \mathrm{H}$ NMR signals assigned to the C-21 methyl group, which appear at $\delta_{\mathrm{H}}=0.921$ and $0.953 \mathrm{ppm}$ in 18a and 18b diastereoisomers, respectively. Based on these NMR measurements, the relative ratio of $\mathbf{1 8 a : 1 8 b}$ was determined as 1.0:1.0. Subsequently, the diastereoisomers mixture was separated by a semi-preparative HPLC system, allowing obtaining the analogs $18 \mathrm{a}$ and $\mathbf{1 8 b}$.

The structure and stereochemistry at C-22 of compounds $\mathbf{1 8 a}$ and $\mathbf{1 8 b}$ was established by a simple comparison of ${ }^{1} \mathrm{H}$ - and ${ }^{13} \mathrm{C}$-NMR spectra obtained for derivatives 20a and 20b, which were previously reported [41,42]. These comparisons considered chemical shifts $(\delta)$, coupling constants $(J)$, and multiplicities of signals corresponding to H-22, H-23a, H-23b, and $\mathrm{CH}_{3}-21\left({ }^{1} \mathrm{H}-\mathrm{NMR}\right)$ and chemical shifts $(\delta)$ in ${ }^{13} \mathrm{C}-\mathrm{NMR}$ of both epimers. The main differences in these spectroscopic parameters are listed in Table 2.

Table 2. Comparison between signals of ${ }^{1} \mathrm{H}-\left(500.1 \mathrm{MHz}, \mathrm{CDCl}_{3}\right)$ and ${ }^{13} \mathrm{C}-\left(125.8 \mathrm{MHz}, \mathrm{CDCl}_{3}\right) \mathrm{NMR}$ for $\mathrm{H} / \mathrm{C} 21, \mathrm{H} / \mathrm{C} 22$, and H/C23a-b, for the epimers $\mathbf{1 8 a}$ and $\mathbf{1 8 b}$.

\begin{tabular}{ccc}
\hline H/C Signal & Compound 18a & Compound 18b \\
\hline $\mathrm{H}-21$ & $0.921 \mathrm{ppm}(3 \mathrm{H}, \mathrm{d}, J=6.7 \mathrm{~Hz})$ & $0.953 \mathrm{ppm}(3 \mathrm{H}, \mathrm{d}, J=7.0 \mathrm{~Hz})$ \\
$\mathrm{H}-22$ & $3.66-3.61 \mathrm{ppm}(1 \mathrm{H}, \mathrm{m})$ & $3.51 \mathrm{ppm}(1 \mathrm{H}, \mathrm{t}, J=10.2 \mathrm{~Hz})$ \\
$\mathrm{H}-23 \mathrm{a}$ & $3.80 \mathrm{ppm}(1 \mathrm{H}, \mathrm{ddd}, J=8.9,3.3$ and $1.2 \mathrm{~Hz})$ & $3.83-3.76 \mathrm{ppm}(1 \mathrm{H}, \mathrm{m})$ \\
$\mathrm{H}-23 \mathrm{~b}$ & $3.52 \mathrm{ppm}(1 \mathrm{H}, \mathrm{dd}, J=10.8$ and $3.3 \mathrm{~Hz})$ & $3.69-3.57 \mathrm{ppm}(1 \mathrm{H}, \mathrm{m})$ \\
$\mathrm{C} 21$ & $12.73 \mathrm{ppm}$ & $13.15 \mathrm{ppm}$ \\
$\mathrm{C} 22$ & $74.14 \mathrm{ppm}$ & $73.92 \mathrm{ppm}$ \\
$\mathrm{C} 23$ & $66.16 \mathrm{ppm}$ & $62.54 \mathrm{ppm}$ \\
\hline
\end{tabular}

Similarly, a Sharpless dihydroxylation of derivative 30 produced the $\mathbf{1 9 a} \mathbf{1 9 b}$ diastereoisomers mixture with a total $80.8 \%$ yield. The diastereomeric ratio of each glycol in the mixture was 1.0:1.0 (established by the integration of ${ }^{1} \mathrm{H}-\mathrm{NMR}$ signals assigned to the C-21 methyl group, which appear at $\delta_{\mathrm{H}}=0.917$ and $0.954 \mathrm{ppm}$ in 19a and 19b diastereoisomers, respectively). The diastereoisomers mixture was separated by semi-preparative HPLC system, allowing obtaining analogs 19a and 19b. Similar to the above, the main differences in spectroscopic parameters of epimers are listed in Table 3.

Table 3. Comparison between signals of ${ }^{1} \mathrm{H}-\left(500.1 \mathrm{MHz}, \mathrm{CDCl}_{3}\right)$ and ${ }^{13} \mathrm{C}-\left(125.8 \mathrm{MHz}, \mathrm{CDCl}_{3}\right) \mathrm{NMR}$ for $\mathrm{H} / \mathrm{C} 21, \mathrm{H} / \mathrm{C} 22$, and H/C23a-b, for the epimers $19 \mathrm{a}$ and $\mathbf{1 9 b}$.

\begin{tabular}{ccc}
\hline H/C Signal & Compound 19a & Compound 19b \\
\hline $\mathrm{H}-21$ & $0.917 \mathrm{ppm}(3 \mathrm{H}, \mathrm{d}, J=6.4 \mathrm{~Hz})$ & $0.954 \mathrm{ppm}(3 \mathrm{H}, \mathrm{d}, J=6.7 \mathrm{~Hz})$ \\
$\mathrm{H}-22$ & $3.75-3.39 \mathrm{ppm}(1 \mathrm{H}, \mathrm{m})$ & $3.51 \mathrm{ppm}(1 \mathrm{H}, \mathrm{t}, J=10.2 \mathrm{~Hz})$ \\
$\mathrm{H}-23 \mathrm{a}$ & $3.87-3.76 \mathrm{ppm}(1 \mathrm{H}, \mathrm{m})$ & $3.84-3.76 \mathrm{ppm}(1 \mathrm{H}, \mathrm{m})$ \\
$\mathrm{H}-23 \mathrm{~b}$ & $3.75-3.39 \mathrm{ppm}(1 \mathrm{H}, \mathrm{m})$ & $3.71-3.59 \mathrm{ppm}(1 \mathrm{H}, \mathrm{m})$ \\
$\mathrm{C} 21$ & $12.73 \mathrm{ppm}$ & $13.13 \mathrm{ppm}$ \\
$\mathrm{C} 22$ & $75.56 \mathrm{ppm}$ & $73.90 \mathrm{ppm}$ \\
$\mathrm{C} 23$ & $61.15 \mathrm{ppm}$ & $62.52 \mathrm{ppm}$ \\
\hline
\end{tabular}

In summary, four new BRs 24-norcholane type analogs conjugated at the C-3 position with benzoate groups substituted with electron donor and electron-withdrawing groups in the $p$-position (compounds 18a, 18b, 19a and 19b) have been synthesized and characterized.

\subsection{Biological}

In this work, the activity of new BR 24-norcholane type analogs conjugated at the C-3 position was evaluated using the Rice Lamina Inclination Test. The results of this test were compared with those obtained for other free analogs of 24-norcholane type (analogs 20a and 20b [38]) and with brassinolide. This assay was used because of its specificity and high 
sensitivity for 1 and their analogs [31,52,53]. The bending angles were measured as the difference between the induced angle produced by treatment with each compound and that found for the negative control. Results obtained for 1, which was used as positive control, and BR analogs 18a, 18b, 19a, 19b, 20a, and 20b are listed in Table 4.

Table 4. Comparison between BRs C-3 conjugated 24-norcholane and free 24-norcholane type analogs on lamina inclination of rice seedlings.

\begin{tabular}{cccc}
\hline \multicolumn{4}{c}{$\begin{array}{c}\text { Bending Angle between Laminae and Sheaths } \\
\text { (Degrees } \pm \text { SD) }\end{array}$} \\
\hline Compounds & $\mathbf{1} \times \mathbf{1 0}^{-\mathbf{8}} \mathbf{M}$ & $\mathbf{1} \times \mathbf{1 0}^{-\mathbf{7}} \mathbf{M}$ & $\mathbf{1} \times \mathbf{1 0}^{-\mathbf{6}} \mathbf{M}$ \\
\hline $\mathbf{1}(\mathrm{C}+)$ & $31 \pm 11$ & $41 \pm 4.5$ & $70 \pm 7.6$ \\
$\mathbf{1 8 a}$ & $61 \pm 6.3^{*}$ & $68 \pm 9.6^{*}$ & $46 \pm 7.5^{*}$ \\
$\mathbf{1 8 b}$ & $64 \pm 3.3^{*}$ & $48 \pm 2.9$ & $14 \pm 4.8^{*}$ \\
$\mathbf{1 9 a}$ & $43 \pm 5.0^{*}$ & $58 \pm 2.4^{*}$ & $68 \pm 9.6$ \\
$\mathbf{1 9 b}$ & $68 \pm 5.0^{*}$ & $61 \pm 2.5^{*}$ & $30 \pm 0.0^{*}$ \\
$\mathbf{2 0 a}{ }^{+}$ & $45 \pm 9.5^{*}$ & $31 \pm 5.0$ & $24 \pm 5.8^{*}$ \\
$\mathbf{2 0 b}{ }^{+}$ & $35 \pm 3.0$ & $60 \pm 3.0^{*}$ & $62 \pm 12$ \\
Control $(\mathrm{C}-)$ & $7 \pm 5.0$ & \\
\hline
\end{tabular}

${ }^{\dagger}$ Data previously obtained and reported in reference [38]. Brassinolide (1) was used as positive control. The negative control only contained sterile distilled water. These values represent the mean \pm standard deviation of two independent experiments with at least six replicates each $(n=12)$. ( $\left.{ }^{*}\right)$ Represents experiments with a significant difference between positive control (1) and analog treatments at $p<0.05$ significance level (least square differences (LSD) $t$-test).

Interestingly, these data clearly indicate that 24-nor-5 $\alpha$-cholane type analogs conjugated at C-3 exhibit interesting growth-promoting activity. These results are in line with previous studies for other analogs of 24-norcholane type [38,48]. All C-3 conjugated analogs exhibit higher activity than brassinolide at the lowest concentrations $\left(1 \times 10^{-8}\right.$ and $\left.1 \times 10^{-7} \mathrm{M}\right)$ (Figure 4 and Table 4$)$.

To simplify the data analysis, we will consider the data obtained at $1 \times 10^{-8}$ and $1 \times 10^{-7} \mathrm{M}$ to analyze the correlation between chemical structure and biological activity. The results indicate that at these concentrations, $\mathbf{1 8 b}$ and $\mathbf{1 9 b}$ are the most active in the series of conjugated analogs $\left(\mathbf{1 9 b}\right.$ was the most active at the concentration of $1 \times 10^{-8}$ $\mathrm{M}$, whereas 18a was the most active at the concentration of $1 \times 10^{-7} \mathrm{M}$ ) (see Table 3), and they were more active than the free analogs 20a and 20b. Another important effect to consider is related to the configuration on the C-22 carbon of the side chain. Thus, at the concentration of $1 \times 10^{-8}$, analogs 18a and 19a with $C-22(R)$ configuration are less active than analogs $\mathbf{1 8 b}$ and $\mathbf{1 9 b}$ with $C-22(S)$ configuration. However, an opposite effect is observed for analogs 20a and 20b. Similarly, at the concentration of $1 \times 10^{-7} \mathrm{M}$, the analogs $19 \mathrm{~b}$ and $20 \mathrm{~b}$ with $\mathrm{C}-22(S)$ configuration are more active that analogs $19 \mathrm{a}$ and $20 \mathrm{a}$ with $\mathrm{C}$ $22(R)$ configuration. However, an opposite effect is observed for analogs 18a and $\mathbf{1 8 b}$. The results observed for the pairs $\mathbf{1 8 a / 1 8 b}\left(\right.$ at $1 \times 10^{-7} \mathrm{M}$ ) and $\mathbf{2 0 a} / \mathbf{2 0 b}\left(\right.$ at $1 \times 10^{-8} \mathrm{M}$ ) would be aligned with those reported for natural occurring BRs with an intact side chain, which indicates that glycol function with $\mathrm{C}-22(R)$ and $\mathrm{C}-23(R)$ configuration appears essential for a high biological activity and are more active than those with C-22(S) and C-23(S) configuration $[3,54]$. However, these apparently contradictory structural effects of BRs analogs could be explained in attributed to the shorter side chains. This structural feature could give a greater rotational freedom degree. 


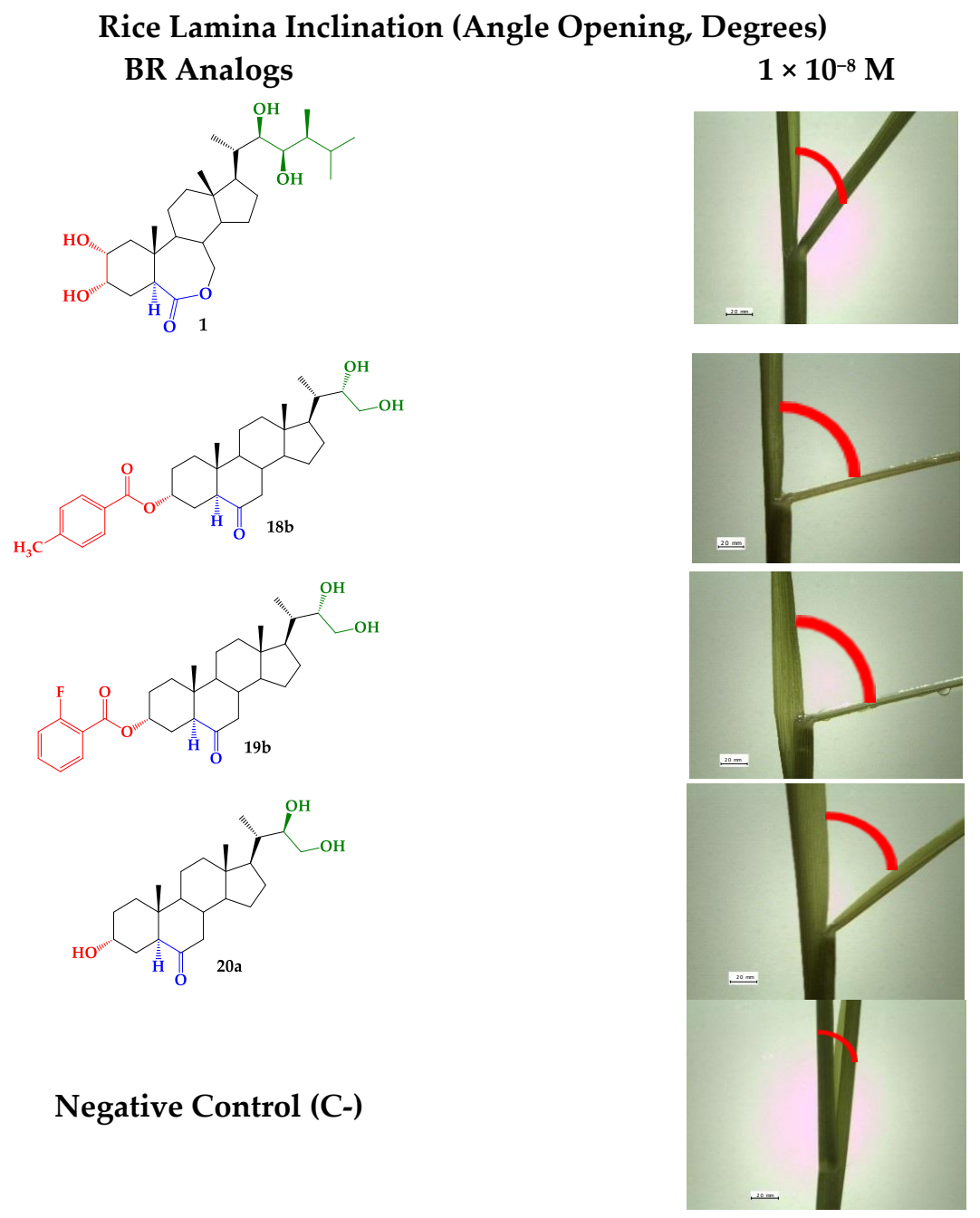

Figure 4. Rice-lamina assays using the second leaf lamina joints of excised leaf segments treated with BR analogs $\left(\mathbf{1 8 b}, \mathbf{1 9 b}\right.$, and 20a) at $1 \times 10^{-8} \mathrm{M}$. Brassinolide (1) was used as positive control at the same concentrations. The negative control only contained sterile distilled water.

\section{Materials and Methods}

\subsection{Chemistry}

All reagents were purchased from commercial suppliers and used without further purification. Melting points were measured on a SMP3 apparatus (Stuart-Scientific, now Merck KGaA, Darmstadt, Germany) and are uncorrected. ${ }^{1} \mathrm{H}-,{ }^{13} \mathrm{C}-,{ }^{13} \mathrm{C}-\mathrm{DEPT}-135$, gs 2D HSQC, and gs $2 \mathrm{D} \mathrm{HMBC}$ NMR spectra were recorded in $\mathrm{CDCl}_{3}$ and $\mathrm{MeOD}$ solutions, and they are referenced to the residual peaks of $\mathrm{CHCl}_{3}$ at $\delta=7.26 \mathrm{ppm}$ and $\delta=77.00 \mathrm{ppm}$ for ${ }^{1} \mathrm{H}$ and ${ }^{13} \mathrm{C}$, respectively and $\mathrm{CD}_{3} \mathrm{OD}$ at $\delta=3.30 \mathrm{ppm}$ and $\delta=49.00 \mathrm{ppm}$ for ${ }^{1} \mathrm{H}$ and ${ }^{13} \mathrm{C}$, on an Avance 400 Digital NMR spectrometer (Bruker, Rheinstetten, Germany) operating at $400.1 \mathrm{MHz}$ for ${ }^{1} \mathrm{H}$ and $100.6 \mathrm{MHz}$ for ${ }^{13} \mathrm{C}$, and JEOL JNM-ECA $500 \mathrm{NMR}$ spectrometer (JEOL, Tokyo, Japan) operating at $500.16 \mathrm{MHz}$ for ${ }^{1} \mathrm{H}, 125.77 \mathrm{MHz}$ for ${ }^{13} \mathrm{C}$, and $470.62 \mathrm{MHz}$ for ${ }^{19} \mathrm{~F}$. Chemical shifts are reported in ppm and coupling constants $(J)$ are given in Hz; multiplicities are reported as follows: singlet (s), doublet (d), doublet of doublets $(\mathrm{dd})$, doublet of triplets $(\mathrm{dt})$, triplet $(\mathrm{t})$, quartet $(\mathrm{q})$, multiplet $(\mathrm{m})$, and broad singlet (bs). IR spectra were recorded as KBr disks in a Fourier Transform Infrared (FT-IR) 6700 spectrometer (Nicolet, Thermo Scientific, San Jose, CA, USA) and frequencies are reported in $\mathrm{cm}^{-1}$. High-resolution mass spectra (HRMS) were recorded in an API HRMS instrument, and the samples were dissolved in chloroform (or chloroform: methanol; 1:1; $v / v$, in the case of hydroxylated compounds) to a concentration of $10 \mu \mathrm{g} \mathrm{mL}^{-1}$. The ASAP (Atmospheric Solids Analysis Probe) was dipped into the sample solution, placed into 
the ion source, and analyzed in full scan mode. The source of the Synapt G2-Si mass spectrometer (Waters, Manchester, UK) was operated in positive ionization mode ( $\mathrm{ASAP}^{+}$), if not stated otherwise, at a source temperature of $120^{\circ} \mathrm{C}$. The corona needle current was kept at $5 \mu \mathrm{A}$ and the collision energy was kept at $4 \mathrm{~V}$. The probe temperature was ramped up from 50 to $600{ }^{\circ} \mathrm{C}$ in $3 \mathrm{~min}$. Data were acquired from 50 to $1000 \mathrm{Da}$ with $1.0 \mathrm{~s}$ scan time in high-resolution mode. The data were processed using the Masslynx 4.1 software (Waters, Milford, MA, USA). A mass accuracy of 1 ppm or less was achieved with the described instrumentation for all compounds. For analytical TLC, silica gel 60 in a $0.25 \mathrm{~mm}$ layer was used, and TLC spots were detected by heating after spraying with $10 \% \mathrm{H}_{2} \mathrm{SO}_{4}$ in $\mathrm{H}_{2} \mathrm{O}$. Chromatographic separations were carried out by conventional column on silica gel 60 (230-400 mesh) using EtOAc-hexane gradients of increasing polarity. All organic extracts were dried over anhydrous magnesium sulfate and evaporated under reduced pressure, below $40{ }^{\circ} \mathrm{C}$. The HPLC system consisted of a Waters semi-preparative HPLC system including a quaternary pump, a liquid handler, and UV-Vis and Evaporative Light Scattering Detector (ELSD) detectors. The semi-preparative column was filled with silica gel.

\subsubsection{Synthesis}

$3 \alpha, 6 \alpha$-Diacetoxy-5 $\beta$-cholan-24-oic acid (22)

To a solution of hyodeoxycholic acid (21) $(25.4 \mathrm{~g}, 64.62 \mathrm{mmol})$ in $400 \mathrm{~mL}$ of $\mathrm{CH}_{2} \mathrm{Cl}_{2}$ (DCM), $150 \mathrm{mg}$ of DMAP, $2 \mathrm{~mL}$ of pyridine, and $24.4 \mathrm{~mL}(257.6 \mathrm{mmol})$ of $\mathrm{Ac}_{2} \mathrm{O}$ were added. The reaction mixture was kept under constant stirring and room temperature for $48 \mathrm{~h}$. The end of the reaction was verified by TLC; then, the mixture was concentrated to a volume approximately $50 \mathrm{~mL}$ under reduced pressure. Then, EtOAc $(200 \mathrm{~mL})$ and $200 \mathrm{~mL}$ of $\mathrm{HCl}$ solution $\left(1 \times 10^{-5} \mathrm{M}\right)$ were added. The organic layer was separated and washed with water $(4 \times 50 \mathrm{~mL})$, with saline $(\mathrm{NaCl})$ solution $(3 \times 50 \mathrm{~mL})$ until $\mathrm{pH}=5$, dried over $\mathrm{Na}_{2} \mathrm{SO}_{4}$, and filtered. The solvent was evaporated under reduced pressure, and the crude was re-dissolved in $\mathrm{CH}_{2} \mathrm{Cl}_{2}(16 \mathrm{~mL})$ and chromatographed on silica gel with EtOAc/hexane (20\%, $200 \mathrm{~mL})$. Compound 22 (28.06 g 91.1\% yield) was a colorless solid, m.p. $=109.7-110.9{ }^{\circ} \mathrm{C}\left(106-110{ }^{\circ} \mathrm{C}[44]\right) . \quad \mathrm{IR} v_{\max }\left(\mathrm{cm}^{-1}\right): 3527(\mathrm{O}-\mathrm{H}) ; 2948 ; 2899$ and $2870(\mathrm{C}-\mathrm{H}) ; 1738(\mathrm{C}=\mathrm{O}) ; 1722(\mathrm{C}=\mathrm{O}) ; 1681(\mathrm{C}=\mathrm{O}) ; 1455\left(\mathrm{CH}_{2}\right) ; 1364\left(\mathrm{CH}_{3}\right) ; 1256(\mathrm{C}-\mathrm{O})$; 1242(C-O); 1027 (C-O). ${ }^{1} \mathrm{H}-\mathrm{NMR}\left(400.1 \mathrm{MHz}, \mathrm{CDCl}_{3}\right.$ ) (Figure S1, Supplementary Materials): $\delta(\mathrm{ppm})=5.14-5.10(1 \mathrm{H}, \mathrm{m}, \mathrm{H}-6) ; 4.71-4.65(1 \mathrm{H}, \mathrm{m}, \mathrm{H}-3) ; 2.37(1 \mathrm{H}, \mathrm{ddd}, J=15.3,10.1$ and 5.0 $\mathrm{Hz}, \mathrm{H}-23 \mathrm{a}) ; 2.23$ (1H, ddd, $J=16.0,10.1$, and $6.4 \mathrm{~Hz}, \mathrm{H}-23 \mathrm{~b}) ; 2.02\left(3 \mathrm{H}, \mathrm{s}, \mathrm{CH}_{3} \mathrm{CO}_{2}-\mathrm{C} 6\right) ; 1.99$ $\left(3 \mathrm{H}, \mathrm{s}, \mathrm{CH}_{3} \mathrm{CO}_{2}-\mathrm{C} 3\right) ; 1.97-1.94(1 \mathrm{H}, \mathrm{m}, \mathrm{H}-5) ; 0.95$ (3H, s, H-19); 0.90 (3H, d, J = 6.4 Hz, H-21); $0.62(3 \mathrm{H}, \mathrm{s}, \mathrm{H}-18) .{ }^{13} \mathrm{C}-\mathrm{NMR}\left(100.6 \mathrm{MHz}, \mathrm{CDCl}_{3}\right)$ (Figure $\mathrm{S} 1$, Supplementary Materials) $\delta$ $(\mathrm{ppm})=180.09(\mathrm{C}-24) ; 170.56\left(\mathrm{CH}_{3} \mathrm{CO}_{2}-\mathrm{C} 6\right) ; 170.52\left(\mathrm{CH}_{3} \mathrm{CO}_{2}-\mathrm{C} 3\right) ; 73.66$ (C-3); 70.92 (C-6); 56.06 (C-14); 55.84 (C-17); 45.28 (C-9); 42.81 (C-13); 39.78 (C-5 and C-12); 35.97 (C-10); 35.18 (C-20); 34.96 (C-7); 34.54 (C-8); 31.20 (C-1); 30.93 (C-22); 30.64 (C-23); 28.01 (C-4); 26.35 (C-16); 26.15 (C-2); 24.00 (C-15); 23.19 (C-19); $21.36\left(\mathrm{CH}_{3} \mathrm{CO}_{2}-\mathrm{C} 6\right) ; 21.32\left(\mathrm{CH}_{3} \mathrm{CO}_{2}-\mathrm{C} 3\right) ; 20.61$ (C-11); 18.17 (C-21); 11.95 (C-18).

\section{4-Nor-5 $\beta$-cholan-22-ene-3 $\alpha, 6 \alpha$-diyl diacetate (23)}

To a solution of $22(2.00 \mathrm{~g}, 4.20 \mathrm{mmol})$ in dry benzene $(150 \mathrm{~mL})$ were added $\mathrm{Cu}(\mathrm{OAc})_{2}{ }^{*} \mathrm{H}_{2} \mathrm{O}$ $(200 \mathrm{mg}, 1.0 \mathrm{mmol})$ and pyridine $(2.5 \mathrm{~mL})$. Then, under reflux, $\mathrm{PhI}(\mathrm{OAc})_{2}(7.04 \mathrm{~g}, 21.5 \mathrm{mmol})$ was added in four portions at hourly intervals. After the addition was completed, the reaction was continued for $1 \mathrm{~h}$. The end of the reaction was verified by TLC, and then, the mixture was filtered, and the solvent was evaporated under reduced pressure. The crude was re-dissolved in DCM $(5 \mathrm{~mL})$ and chromatographed on silica gel with PE/EtOAc mixtures of increasing polarity (19.8:0.2 -> 15.8:4.2). The reaction was repeated 5 times under identical conditions. Compound $23(9.0 \mathrm{~g}, 99.6 \%$ yield) was obtained as a colorless solid, m.p. $=89.0-90.9^{\circ} \mathrm{C}\left(88-89^{\circ} \mathrm{C}[45]\right) . \mathrm{IR} v_{\max }\left(\mathrm{cm}^{-1}\right): 3082\left(\mathrm{CH}=\mathrm{CH}_{2}\right) ; 2940 ; 2887$ and $2867(\mathrm{C}-\mathrm{H}) ; 1740(\mathrm{C}=\mathrm{O}) ; 1727(\mathrm{C}=\mathrm{O}) ; 1633(\mathrm{C}=\mathrm{C}) ; 1460\left(\mathrm{CH}_{2}\right) ; 1366\left(\mathrm{CH}_{3}\right) ; 1244(\mathrm{C}-\mathrm{O}) ; 1026$ (C-O); $908\left(\mathrm{CH}=\mathrm{CH}_{2}\right) .{ }^{1} \mathrm{H}-\mathrm{NMR}\left(400.1 \mathrm{MHz}, \mathrm{CDCl}_{3}\right)$ (Figure $\mathrm{S} 2$, Supplementary Materials): $\delta(\mathrm{ppm})=5.65(1 \mathrm{H}, \mathrm{ddd}, J=17.1,10.2$, and $8.4 \mathrm{~Hz}, \mathrm{H}-22) ; 5.16-5.13(1 \mathrm{H}, \mathrm{m}, \mathrm{H}-6) ; 4.90(1 \mathrm{H}$, 
$\mathrm{dd}, J=17.1$ and $2.0 \mathrm{~Hz}, \mathrm{H}-23 \mathrm{a}) ; 4.81(1 \mathrm{H}, \mathrm{dd}, J=10.2$ and $2.0 \mathrm{~Hz}, \mathrm{H}-23 \mathrm{~b}) ; 4.71-4.69(1 \mathrm{H}, \mathrm{m}$, $\mathrm{H}-3) ; 2.07-2.03(1 \mathrm{H}, \mathrm{m}, \mathrm{H}-20) ; 2.04\left(3 \mathrm{H}, \mathrm{s}, \mathrm{CH}_{3} \mathrm{CO}_{2}-\mathrm{C} 6\right) ; 2.01\left(3 \mathrm{H}, \mathrm{s}, \mathrm{CH}_{3} \mathrm{CO}_{2}-\mathrm{C} 3\right) ; 2.00-1.94$ $(1 \mathrm{H}, \mathrm{m}, \mathrm{H}-5) ; 1.02(3 \mathrm{H}, \mathrm{d}, J=6.6 \mathrm{~Hz}, \mathrm{H}-21) ; 0.97(3 \mathrm{H}, \mathrm{s}, \mathrm{H}-19) ; 0.67(3 \mathrm{H}, \mathrm{s}, \mathrm{H}-18) .{ }^{13} \mathrm{C}-\mathrm{NMR}$ $\left(100.6 \mathrm{MHz}, \mathrm{CDCl}_{3}\right)$ (Figure S2, Supplementary Materials) $\delta(\mathrm{ppm})=170.47\left(\mathrm{CH}_{3} \mathrm{CO}_{2}-\mathrm{C} 6\right)$; $170.45\left(\mathrm{CH}_{3} \mathrm{CO}_{2}-\mathrm{C} 3\right) ; 145.06$ (C-22); 111.69 (C-23); 73.70 (C-3); 70.95 (C-6); 56.21 (C-14); 55.59 (C-17); 45.39 (C-9); 42.83 (C-13); 41.13 (C-20); 39.93 (C-5); 39.79 (C-12); 36.07 (C-10); 35.06 (C-1); 34.63 (C-8); 31.30 (C-7); 28.36 (C-16); 26.44 (C-2); 26.25 (C-4); 24.09 (C-15); 23.27 (C-19); $21.41\left(\mathrm{CH}_{3} \mathrm{CO}_{2}-\mathrm{C} 6\right) ; 21.37\left(\mathrm{CH}_{3} \mathrm{CO}_{2}-\mathrm{C} 3\right) ; 20.68$ (C-11); 20.07 (C-21); 12.18 (C-18).

24-Nor-5 $\beta$-chol-22-ene-3 $\alpha, 6 \alpha$-diol (24)

To a solution of $23(8.06 \mathrm{~g}, 18.71 \mathrm{mmol})$ in a mixture $1: 1$ of acetone/MeOH $(60 \mathrm{~mL})$, a $15 \%$ aqueous solution of $\mathrm{K}_{2} \mathrm{CO}_{3}(37.4 \mathrm{mmol})$ was added. The suspension was stirred and refluxed for $7 \mathrm{~h}$. The end of the reaction was verified by TLC. Then, the solvent was removed, the residue was diluted with EtOAc $(80 \mathrm{~mL})$, and the mixture was washed with $3 \times 80 \mathrm{~mL}$ of $\mathrm{HCl}$ solution $\left(1 \times 10^{-3} \mathrm{M}\right)$. The organic layer was dried over $\mathrm{Na}_{2} \mathrm{SO}_{4}$ and filtered. The solvent was evaporated under reduced pressure, and the crude was redissolved in $\mathrm{CH}_{2} \mathrm{Cl}_{2}(15 \mathrm{~mL})$ and chromatographed on silica gel with $\mathrm{PE} / \mathrm{EtOAc}$ mixtures of increasing polarity (19.8:0.2 -> 7.2:12.8). Compound 24 (6.3 g; 97.1\% yield) was obtained as a colorless solid, m.p. $=154.4-155.2^{\circ} \mathrm{C}\left(150-152{ }^{\circ} \mathrm{C}\right.$ [45]). IR $v_{\max }\left(\mathrm{cm}^{-1}\right): 3381(\mathrm{O}-\mathrm{H}) ; 3088$ $\left(\mathrm{CH}=\mathrm{CH}_{2}\right) ; 2934,2889$, and $2868(\mathrm{C}-\mathrm{H}) ; 1637(\mathrm{C}=\mathrm{C}) ; 1462\left(\mathrm{CH}_{2}\right) ; 1336\left(\mathrm{CH}_{3}\right) ; 1269(\mathrm{C}-\mathrm{O})$; 1043 (C-O); $912\left(\mathrm{CH}=\mathrm{CH}_{2}\right) .{ }^{1} \mathrm{H}-\mathrm{NMR}(400.1 \mathrm{MHz}$, Acetone) (Figure S3, Supplementary Materials): $\delta(\mathrm{ppm})=5.66(1 \mathrm{H}, \mathrm{ddd}, J=17.4,10.0$, and $8.6 \mathrm{~Hz}, \mathrm{H}-22) ; 4.90(1 \mathrm{H}, \mathrm{dd}, J=17.1$ and $2.0 \mathrm{~Hz}, \mathrm{H}-23 \mathrm{a}) ; 4.82(1 \mathrm{H}, \mathrm{dd}, J=10.2$ and $2.0 \mathrm{~Hz}, \mathrm{H}-23 \mathrm{~b}) ; 4.02-3.96(1 \mathrm{H}, \mathrm{m}, \mathrm{H}-6)$; 3.48-3.42 (1H, m, H-3); $1.02(3 \mathrm{H}, \mathrm{d}, J=6.6 \mathrm{~Hz}, \mathrm{H}-21) ; 0.91(3 \mathrm{H}, \mathrm{s}, \mathrm{H}-19) ; 0.66(3 \mathrm{H}, \mathrm{s}, \mathrm{H}-18)$. ${ }^{13} \mathrm{C}-\mathrm{NMR}(100.6 \mathrm{MHz}$, Acetone) (Figure S3, Supplementary Materials): $\delta(\mathrm{ppm})=146.00$ (C-22); 112.05 (C-23); 71.72 (C-3); 67.63 (C-6); 57.20 (C-14); 56.40 (C-17); 49.70 (C-9); 43.51 (C-13); 42.09 (C-20); 40.89 (C-5); 40.80 (C-12); 36.65 (C-1); 36.55 (C-10); 35.97 (C-7); 35.70 (C-8); 31.43 (C-4); 30.05 (C-2); 29.15 (C-16); 24.90 (C-15); 24.10 (C-19); 21.54 (C-11); 20.55 (C-21); 12.55 (C-18).

$6 \alpha$-Hydroxy-24-nor-5 $\beta$-chol-22-en-3-one (25), 24-nor-5 $\beta$-chol-22-ene-3,6-dione (26) and $3 \alpha$-hydroxy-24-nor-5 $\beta$-chol-22-en-6-one (27)

A solution of $24(6.0 \mathrm{~g}, 17.3 \mathrm{mmol})$ in DCM $(100 \mathrm{~mL})$ with $3.76 \mathrm{~g}(17.3 \mathrm{mmol})$ of Pyridinium chlorochromate (PCC) in $60 \mathrm{~mL}$ of DCM (added by slow drip) was slowly stirred for $48 \mathrm{~h}$ at room temperature. The end of the reaction was verified by TLC; then, the reaction mixture was filtered on alumina and washed with ethyl acetate $(20 \mathrm{~mL})$. The solvent was evaporated under reduced pressure, and the crude was re-dissolved in $\mathrm{CH}_{2} \mathrm{Cl}_{2}$ $(10 \mathrm{~mL})$ and chromatographed on silica gel with PE/EtOAc mixtures of increasing polarity (19.8:0.2 -> 8.8:11.2). Four fractions were obtained: Fraction I, $1.14 \mathrm{~g}$ (19.1\% yield) of compound 26; Fraction II, $0.141 \mathrm{~g}$ (2.4\% yield) of compound 25; Fraction III, $2.39 \mathrm{~g}$ ( $40.2 \%$ yield) of compound 27; and Fraction IV, $3.58 \mathrm{~g}$ of unreacted 24. The reaction was repeated with compound 24 twice with another $5.5 \mathrm{~g}$ each and $26(2.08 \mathrm{~g}), 25(4.28 \mathrm{~g})$, and $27(0.258 \mathrm{~g})$ were obtained.

Compound 25 was obtained as a colorless solid. ${ }^{1} \mathrm{H}-\mathrm{NMR}\left(400.1 \mathrm{MHz}, \mathrm{CDCl}_{3}\right)$ (Figure S4, Supplementary Materials): $\delta(\mathrm{ppm})=5.68(1 \mathrm{H}, \mathrm{ddd}, J=17.1,10.2$, and 8.4 $\mathrm{Hz}, \mathrm{H}-22) ; 4.93(1 \mathrm{H}, \mathrm{dd}, J=17.1$ and $2.0 \mathrm{~Hz}, \mathrm{H}-23 \mathrm{a}) ; 4.84(1 \mathrm{H}, \mathrm{dd}, J=10.2$ and $2.0 \mathrm{~Hz}$, H-23b); 4.15-4.10 (1H, m, H-6); 2.42-2.39 (2H, m, H-4); 1.05 (3H, d, J = 6.6 Hz, H-21); 1.03 $(3 \mathrm{H}, \mathrm{s}, \mathrm{H}-19) ; 0.72(3 \mathrm{H}, \mathrm{s}, \mathrm{H}-18) .{ }^{13} \mathrm{C}-\mathrm{NMR}\left(100.6 \mathrm{MHz}, \mathrm{CDCl}_{3}\right)$ (Figure 44 , Supplementary Materials): $\delta(\mathrm{ppm})=212.63$ (C-3); 145.00 (C-22); 111.77 (C-23); 67.73 (C-6); 56.17 (C-14); 55.55 (C-17); 50.16 (C-9); 42.79 (C-13); 41.15 (C-20); 40.31 (C-5); 39.74 (C-12); 37.08 (C-1); 37.06 (C-7); 36.24 (C-10); 36.02 (C-4); 34.56 (C-8); 34.40 (C-2); 28.35 (C-16); 24.17 (C-15); 22.85 (C-19); 21.08 (C-11); 20.10 (C-21); 12.23 (C-18).

Compound 26 was obtained as a colorless solid, m.p. $=177.5-178.9^{\circ} \mathrm{C}\left(197-200^{\circ} \mathrm{C}\right.$ [45] $)$. IR $v_{\max }\left(\mathrm{cm}^{-1}\right)$ : $3073\left(\mathrm{CH}=\mathrm{CH}_{2}\right) ; 2964,2947,2873$, and $2855(\mathrm{C}-\mathrm{H}) ; 1716(\mathrm{C}=\mathrm{O}) ; 1693(\mathrm{C}=\mathrm{O})$; $1632(\mathrm{C}=\mathrm{C}) ; 1466\left(\mathrm{CH}_{2}\right) ; 1382\left(\mathrm{CH}_{3}\right) ; 1245(\mathrm{C}-\mathrm{O}) ; 1216(\mathrm{C}-\mathrm{O}) ; 908\left(\mathrm{CH}=\mathrm{CH}_{2}\right) .{ }^{1} \mathrm{H}-\mathrm{NMR}(400.1$ 
$\mathrm{MHz}, \mathrm{CDCl}_{3}$ ) (Figure S5, Supplementary Materials): $\delta(\mathrm{ppm})=5.68(1 \mathrm{H}, \mathrm{ddd}, J=17.1,10.2$, and $8.4 \mathrm{~Hz}, \mathrm{H}-22) ; 4.94(1 \mathrm{H}, \mathrm{dd}, J=17.1$ and $2.0 \mathrm{~Hz}, \mathrm{H}-23 \mathrm{a}) ; 4.86(1 \mathrm{H}, \mathrm{dd}, J=10.2$ and 2.0 $\mathrm{Hz}, \mathrm{H}-23 \mathrm{~b}) ; 2.67$ (1H, dd, $J=15.0$ and $13.2 \mathrm{~Hz}, \mathrm{H}-4 \mathrm{a}) ; 2.50(1 \mathrm{H}, \mathrm{dd}, J=12.5$ and $4.9 \mathrm{~Hz}, \mathrm{H}-5)$; $2.42(1 \mathrm{H}, \mathrm{dd}, J=14.3$ and $5.3 \mathrm{~Hz}, \mathrm{H}-1 \mathrm{a}) ; 2.36(1 \mathrm{H}, \mathrm{dd}, J=5.2$ and $1.9 \mathrm{~Hz}, \mathrm{H}-4 \mathrm{~b}) ; 1.07(3 \mathrm{H}$, $\mathrm{d}, J=6.5 \mathrm{~Hz}, \mathrm{H}-21) ; 0.98$ (3H, s, H-19); 0.74 (3H, s, H-18). ${ }^{13} \mathrm{C}-\mathrm{NMR}\left(100.6 \mathrm{MHz}, \mathrm{CDCl}_{3}\right)$ (Figure S5, Supplementary Materials): $\delta$ (ppm) = 210.82 (C-6); 208.65 (C-3); 144.72 (C-22); 111.99 (C-23); 59.74 (C-5); 56.86 (C-14); 55.40 (C-17); 43.02 (C-13); 42.16 (C-7); 41.06 (C-20); 40.98 (C-9); 39.90 (C-4); 39.41 (C-12); 38.31 (C-10); 36.69 (C-8); 36.49 (C-1); 35.78 (C-2); 28.21 (C-16); 23.93 (C-15); 22.48 (C-19); 21.30 (C-11); 20.09 (C-21); 12.17 (C-18).

Compound 27 was obtained as a colorless solid, m.p. $=151.9-153.6^{\circ} \mathrm{C}$. IR $v_{\max }\left(\mathrm{cm}^{-1}\right)$ : $3288(\mathrm{O}-\mathrm{H}) ; 3074\left(\mathrm{CH}=\mathrm{CH}_{2}\right) ; 2970,2949$, and $2867(\mathrm{C}-\mathrm{H}) ; 1702(\mathrm{C}=\mathrm{O}) ; 1637(\mathrm{C}=\mathrm{C}) ; 1458$ $\left(\mathrm{CH}_{2}\right) ; 1379\left(\mathrm{CH}_{3}\right) ; 1248(\mathrm{C}-\mathrm{O}) ; 1064(\mathrm{C}-\mathrm{O}) ; 912\left(\mathrm{CH}=\mathrm{CH}_{2}\right) .{ }^{1} \mathrm{H}-\mathrm{NMR}\left(400.1 \mathrm{MHz}, \mathrm{CDCl}_{3}\right)$ (Figure S6, Supplementary Materials): $\delta(\mathrm{ppm})=5.67(1 \mathrm{H}$, ddd, $J=17.1,10.1$, and $8.4 \mathrm{~Hz}$, $\mathrm{H}-22) ; 4.93(1 \mathrm{H}, \mathrm{dd}, J=17.1$ and $2.0 \mathrm{~Hz}, \mathrm{H}-23 \mathrm{a}) ; 4.85(1 \mathrm{H}, \mathrm{dd}, J=10.1$ and $2.0 \mathrm{~Hz}, \mathrm{H}-23 \mathrm{~b})$; 3.70-3.62 (1H, m, H-3); 2.20-2.18 (2H, m, H-7); 2.14 (1H, dd, $J=12.1$ and $5.1 \mathrm{~Hz}, \mathrm{H}-5)$; $1.05(3 \mathrm{H}, \mathrm{d}, \mathrm{J}=6.6 \mathrm{~Hz}, \mathrm{H}-21) ; 0.86$ (3H, s, H-19); 0.70 (3H, s, H-18). ${ }^{13} \mathrm{C}-\mathrm{NMR}(100.6 \mathrm{MHz}$, $\mathrm{CDCl}_{3}$ ) (Figure S6, Supplementary Materials): $\delta(\mathrm{ppm})=213.89(\mathrm{C}-6) ; 144.89(\mathrm{C}-22) ; 111.87$ (C-23); 70.18 (C-3); 59.41 (C-5); 56.89 (C-14); 55.41 (C-17); 43.04 (C-13); 42.93 (C-7); 41.11 (C-20); 40.07 (C-9); 39.53 (C-12); 37.99 (C-10); 37.07 (C-8); 34.86 (C-1); 34.38 (C-4); 29.86 (C-2); 28.26 (C-16); 23.99 (C-15); 23.17 (C-19); 20.84 (C-11); 20.08 (C-21); 12.15 (C-18).

$3 \alpha$-Hydroxy-24-nor-5 $\beta$-chol-22-en-6-one (27) from 24-nor-5 $\beta$-chol-22-ene-3,6-dione (26)

A solution of compound $26(3.22 \mathrm{~g}, 9.4 \mathrm{mmol})$ was prepared in $100 \mathrm{~mL}$ of $1: 1 \mathrm{MeOH} / \mathrm{THF}$ mixture. This solution was placed in a bath of ice-water between 0 and $5{ }^{\circ} \mathrm{C}$. Subsequently, $117.9 \mathrm{mg}$ ( $3.15 \mathrm{mmol})$ of $\mathrm{NaBH}_{4}$ were added in four portions (approximately $29.5 \mathrm{mg}$ each) maintaining the temperature and with slow stirring. The end of the reaction was verified by TLC, $10 \mathrm{~mL}$ of acetone, and subsequently, $5 \mathrm{~mL}$ of $\mathrm{HCl} 2.5 \%$ were added, maintaining the reaction temperature. The reaction mixture was concentrated by evaporation under reduced pressure to a volume of about $15 \mathrm{~mL}$, and then, EtOAc $(50 \mathrm{~mL})$ was added. The organic layer was washed with saturated solution of $\mathrm{NaHCO}_{3}(20 \mathrm{~mL})$ and water $(2 \times 30 \mathrm{~mL})$, dried over anhydrous $\mathrm{MgSO}_{4}$, and filtered. The solvent was evaporated under reduced pressure. The crude was re-dissolved in $\mathrm{CH}_{2} \mathrm{Cl}_{2}(5 \mathrm{~mL})$ and chromatographed on silica gel with PE/EtOAc mixtures of increasing polarity (9.8:02 -> 5.8:4.2). Two fractions were obtained: Fraction I, $0.753 \mathrm{~g}$ of unreacted compound 26; Fraction II, $2.47 \mathrm{~g}$ (76.3\% yield) of compound 27. The melting point and spectroscopic properties $\left({ }^{1} \mathrm{H}\right.$ - and $\left.{ }^{13} \mathrm{C}-\mathrm{NMR}\right)$ of compounds $\mathbf{2 6}$ and 27 were identical to those reported above for the direct oxidation of compound 24 .

$3 \alpha$-Hydroxy-24-nor-5 $\alpha$-chol-22-en-6-one (28)

Compound $27(6.08 \mathrm{~g}, 17.65 \mathrm{mmol})$ was dissolved in $100 \mathrm{~mL}$ of $2.5 \%$ v/v HCl-MeOH at room temperature and constant agitation for $48 \mathrm{~h}$. The end of the reaction was verified by TLC. The solvent was evaporated under reduced pressure, and the crude was re-dissolved in $60 \mathrm{~mL}$ of EtOAc. The organic layer was washed with saturated solution of $\mathrm{NaHCO}_{3}(2 \times 15 \mathrm{~mL})$ and water $(2 \times 30 \mathrm{~mL})$, dried over $\mathrm{MgSO}_{4}$, and filtered. The solvent was evaporated under reduced pressure. The crude was re-dissolved in $\mathrm{CH}_{2} \mathrm{Cl}_{2}$ (5 mL) and chromatographed on silica gel with PE/EtOAc mixtures of increasing polarity (9.8:0.2 -> 4.0:6.0). Two fractions were obtained: Fraction I, $4.55 \mathrm{~g}$ (74.8\% yield) of compound 28 and Fraction II, $1.15 \mathrm{~g}$ of unreacted compound 27. Compound 28 was obtained as a colorless solid, m.p. $=169.9-170.9{ }^{\circ} \mathrm{C} .{ }^{1} \mathrm{H}-\mathrm{NMR}\left(400.1 \mathrm{MHz}, \mathrm{CDCl}_{3}\right)$ (Figure S7, Supplementary Materials): $\delta(\mathrm{ppm})=5.68(1 \mathrm{H}, \mathrm{ddd}, J=17.0,10.1$, and $8.3 \mathrm{~Hz}, \mathrm{H}-22) ; 4.93(1 \mathrm{H}$, $\mathrm{dd}, J=17.0$ and $2.0 \mathrm{~Hz}, \mathrm{H}-23 \mathrm{a}) ; 4.84(1 \mathrm{H}, \mathrm{dd}, J=10.1$ and $2.0 \mathrm{~Hz}, \mathrm{H}-23 \mathrm{~b}) ; 4.20-4.17(1 \mathrm{H}, \mathrm{m}$, $\mathrm{H}-3) ; 2.74(1 \mathrm{H}, \mathrm{t}, J=7.9 \mathrm{~Hz}, \mathrm{H}-5) ; 2.32(1 \mathrm{H}, \mathrm{dd}, J=13.1$ and $4.5 \mathrm{~Hz}, \mathrm{H}-7 \alpha) ; 2.15-1.97(3 \mathrm{H}$, $\mathrm{m}, \mathrm{H}-20, \mathrm{H}-12 \alpha$, and H-7 $\beta) ; 1.06(3 \mathrm{H}, \mathrm{d}, J=6.6 \mathrm{~Hz}, \mathrm{H}-21) ; 0.75$ (3H, s, H-19); 0.71 (3H, s, H-18). ${ }^{13} \mathrm{C}-\mathrm{NMR}\left(100.6 \mathrm{MHz}, \mathrm{CDCl}_{3}\right.$ ) (Figure S7, Supplementary Materials): $\delta(\mathrm{ppm})=$ 
212.67 (C-6); 144.96 (C-22); 111.81 (C-23); 65.47 (C-3); 56.84 (C-14); 55.37 (C-17); 53.88 (C-9); 51.69 (C-5); 46.86 (C-7); 42.96 (C-13); 41.57 (C-10); 41.12 (C-20); 39.41 (C-12); 37.98 (C-8); 31.69 (C-1); 28.19 (C-2 and C-4); 27.71 (C-16); 23.93 (C-15); 21.07 (C-11); 20.07 (C-21); 12.32 (C-19); 12.20 (C-18). HRMS (API+) (Figure S14, Supplementary Materials): $m / z$ calculated for $\mathrm{C}_{23} \mathrm{H}_{37} \mathrm{O}_{2}\left([\mathrm{M}+\mathrm{H}]^{+}\right)$345.2794; found 345.2795.

6-Oxo-24-nor-5 $\alpha$-chol-22-en-3 $\alpha$-yl 4-methylbenzoate (29)

A solution of compound 28 (150 mg, $0.44 \mathrm{mmol}$ ) and DMAP (44 mg, $0.36 \mathrm{mmol}$ ) was prepared in $3 \mathrm{~mL}$ of anhydrous pyridine. To this solution, 4-methylbenzoyl chloride $174 \mu \mathrm{L}$ (1.32 mmol) was added by slow dripping, and the reaction was maintained at room temperature with constant stirring for $2 \mathrm{~h}$. The end of the reaction was verified by TLC. After completion of the reaction, $3 \mathrm{~mL}$ of hot water was added. After an additional $20 \mathrm{~min}$ of stirring, the mixture was extracted with EtOAc $(20 \mathrm{~mL})$ and washed successively with saturated $\mathrm{NaHCO}_{3}$ solution $(2 \times 10 \mathrm{~mL})$ and water $(2 \times 10 \mathrm{~mL})$, dried over anhydrous $\mathrm{MgSO}_{4}$, and filtered. The solvent was evaporated under reduced pressure, and the crude was redissolved in $\mathrm{CH}_{2} \mathrm{Cl}_{2}(5 \mathrm{~mL})$ and chromatographed on silica gel with EtOAc/cyclohexane (1.0:19) mixture. Compound 29 (117 mg, 87.9\% yield) was obtained as a colorless solid, m.p. $=133.3-135.2{ }^{\circ} \mathrm{C} .{ }^{1} \mathrm{H}-\mathrm{NMR}\left(500.16 \mathrm{MHz}, \mathrm{CDCl}_{3}\right)$ (Figure S8, Supplementary Materials): $\delta$ $(\mathrm{ppm})=7.90\left(2 \mathrm{H}, \mathrm{d}, J=8.0 \mathrm{~Hz}, \mathrm{HAr}-2^{\prime}\right) ; 7.24\left(2 \mathrm{H}, \mathrm{d}, J=8.0 \mathrm{~Hz}, \mathrm{HAr}-3^{\prime}\right) ; 5.65(1 \mathrm{H}, \mathrm{ddd}$, $J=17.1,10.1$ and $8.6 \mathrm{~Hz}, \mathrm{H}-22) ; 5.36-5.34(1 \mathrm{H}, \mathrm{m}, \mathrm{H}-3) ; 4.91(1 \mathrm{H}$, ddd, $J=17.1,1.8$ and $0.9 \mathrm{~Hz}, \mathrm{H}-23 \mathrm{a}) ; 4.82(1 \mathrm{H}, \mathrm{dd}, J=10.1$ and $1.8 \mathrm{~Hz}, \mathrm{H}-23 \mathrm{~b}) ; 2.66(1 \mathrm{H}, \mathrm{dd}, J=12.5$ and $3.1 \mathrm{~Hz}$, $\mathrm{H}-5) ; 2.41\left(3 \mathrm{H}, \mathrm{s}, \mathrm{CH}_{3}-\mathrm{Ar}\right) ; 2.32(1 \mathrm{H}, \mathrm{dd}, J=13.1$ and $4.6 \mathrm{~Hz}, \mathrm{H}-7 \alpha) ; 1.03(3 \mathrm{H}, \mathrm{d}, J=6.7 \mathrm{~Hz}$, $\mathrm{H}-21) ; 0.786$ (3H, s, H-19); 0.695 (3H, s, H-18). ${ }^{13} \mathrm{C}-\mathrm{NMR}\left(125.77 \mathrm{MHz}, \mathrm{CDCl}_{3}\right.$ ) (Figure S8, Supplementary Materials): $\delta(\mathrm{ppm})=211.92(\mathrm{C}-6) ; 165.78\left(\mathrm{CO}_{2}-\mathrm{Ar}\right) ; 145.01$ (C-22); 143.61 (C4'-Ar); 129.60 (C2'-Ar and C6 $\left.{ }^{\prime}-\mathrm{Ar}\right) ; 129.18$ (C3'-Ar and $\left.\mathrm{C}^{\prime}{ }^{\prime}-\mathrm{Ar}\right) ; 128.18$ (C1'-Ar); 111.95 (C-23); 69.37 (C-3); 56.86 (C-14); 55.50 (C-17); 54.09 (C-9); 53.01 (C-5); 46.85 (C-7); 43.05 (C-13); 41.48 (C-10); 41.24 (C-20); 39.44 (C-12); 38.06 (C-8); 32.81 (C-1); 28.31 (C-16); 25.57 (C-2); 25.25 (C-4); 24.02 (C-15); 21.79 ( $\left.\mathrm{CH}_{3}-\mathrm{Ar}\right) ; 21.22$ (C-11); 20.16 (C-21); 12.57 (C-19); 12.31 (C-18). HRMS (API+) (Figure S15, Supplementary Materials): $m / z$ calculated for $\mathrm{C}_{31} \mathrm{H}_{43} \mathrm{O}_{3}$ $\left([\mathrm{M}+\mathrm{H}]^{+}\right)$463.3212; found 463.3212 .

\section{6-Oxo-24-nor-5 $\alpha$-chol-22-en-3 $\alpha$-yl 2-fluorobenzoate (30)}

A solution of compound 29 (120 mg, $0.348 \mathrm{mmol})$ and DMAP (35 mg, $0.286 \mathrm{mmol})$ was prepared in $3 \mathrm{~mL}$ of anhydrous pyridine. To this solution, 2-fluorobenzoyl chloride $123.5 \mu \mathrm{L}(1.05 \mathrm{mmol})$ was added by slow dripping, and the reaction was maintained at room temperature with constant stirring for $3 \mathrm{~h}$. The end of the reaction was verified by TLC. After completion of the reaction, $3 \mathrm{~mL}$ of hot water was added. After an additional $20 \mathrm{~min}$ of stirring, the mixture was extracted with EtOAc $(20 \mathrm{~mL})$ and washed successively with saturated $\mathrm{NaHCO}_{3}$ solution $(2 \times 10 \mathrm{~mL})$ and water $(2 \times 10 \mathrm{~mL})$, dried over anhydrous $\mathrm{MgSO}_{4}$, and filtered. The solvent was evaporated under reduced pressure, and the crude was re-dissolved in $\mathrm{CH}_{2} \mathrm{Cl}_{2}(5 \mathrm{~mL})$ and chromatographed on silica gel with EtOAc/cyclohexane (1.0:19) mixture. Compound 30 (91 mg, 56.0\% yield) was obtained as a colorless solid, m.p. $=120.6-120.8{ }^{\circ} \mathrm{C} .{ }^{1} \mathrm{H}-\mathrm{NMR}\left(500.16 \mathrm{MHz}, \mathrm{CDCl}_{3}\right)$ (Figure S9, Supplementary Materials): $\delta(\mathrm{ppm})=7.92\left(1 \mathrm{H}, \mathrm{td}, J=7.6\right.$ and $\left.1.8 \mathrm{~Hz}, \mathrm{HAr}-6^{\prime}\right) ; 7.54-7.48$ $\left(1 \mathrm{H}, \mathrm{m}, \mathrm{HAr}-4^{\prime}\right) ; 7.21\left(1 \mathrm{H}, \mathrm{td}, J=7.6\right.$ and $\left.1.2 \mathrm{~Hz}, \mathrm{HAr}-3^{\prime}\right) ; 7.13(1 \mathrm{H}, \mathrm{ddd}, J=10.7,7.6$ and $\left.0.9 \mathrm{~Hz}, \mathrm{HAr}-5^{\prime}\right) ; 5.65(1 \mathrm{H}$, ddd, $J=17.1,10.1$, and $8.6 \mathrm{~Hz}, \mathrm{H}-22) ; 5.42-5.39(1 \mathrm{H}, \mathrm{m}, \mathrm{H}-3) ; 4.90$ $(1 \mathrm{H}, \mathrm{ddd}, J=17.1,1.8$, and $0.9 \mathrm{~Hz}, \mathrm{H}-23 \mathrm{a}) ; 4.82(1 \mathrm{H}, \mathrm{dd}, J=10.1$ and $1.8 \mathrm{~Hz}, \mathrm{H}-23 \mathrm{~b}) ; 2.71$ $(1 \mathrm{H}, \mathrm{dd}, J=12.5$ and $3.1 \mathrm{~Hz}, \mathrm{H}-5) ; 2.31(1 \mathrm{H}, \mathrm{dd}, J=13.1$ and $4.6 \mathrm{~Hz}, \mathrm{H}-7 \alpha) ; 1.03(3 \mathrm{H}, \mathrm{d}$, $J=6.7 \mathrm{~Hz}, \mathrm{H}-21) ; 0.781$ (3H, s, H-19); 0.692 (3H, s, H-18). ${ }^{13} \mathrm{C}-\mathrm{NMR}\left(125.77 \mathrm{MHz}, \mathrm{CDCl}_{3}\right)$ (Figure S9, Supplementary Materials): $\delta(\mathrm{ppm})=212.04(\mathrm{C}-6) ; 163.85\left(\mathrm{~d},{ }^{3} J_{\mathrm{CF}}=3.6 \mathrm{~Hz}\right.$, $\left.\mathrm{CO}_{2}-\mathrm{Ar}\right) ; 161.92\left(\mathrm{~d},{ }^{1} J_{\mathrm{CF}}=259.1 \mathrm{~Hz}, \mathrm{C} 2^{\prime}-\mathrm{Ar}\right) ; 145.02(\mathrm{C}-22) ; 134.44\left(\mathrm{~d},{ }^{3} J_{\mathrm{CF}}=8.4 \mathrm{~Hz}, \mathrm{C} 4^{\prime}-\mathrm{Ar}\right)$; $132.32\left(\mathrm{~d},{ }^{3} J_{\mathrm{CF}}=0.9 \mathrm{~Hz}, \mathrm{C} 6^{\prime}-\mathrm{Ar}\right) ; 124.11\left(\mathrm{~d},{ }^{4} J_{\mathrm{CF}}=3.6 \mathrm{~Hz}, \mathrm{C} 5^{\prime}-\mathrm{Ar}\right) ; 119.38\left(\mathrm{~d},{ }^{2} J_{\mathrm{CF}}=9.6 \mathrm{~Hz}\right.$, $\left.\mathrm{C}^{\prime}-\mathrm{Ar}\right) ; 117.05\left(\mathrm{~d},{ }^{2} J_{\mathrm{CF}}=21.6 \mathrm{~Hz}, \mathrm{C}^{\prime}-\mathrm{Ar}\right) ; 111.93$ (C-23); 70.34 (C-3); 56.82 (C-14); 55.50 (C-17); 53.99 (C-9); 52.79 (C-5); 46.84 (C-7); 43.05 (C-13); 41.42 (C-10); 41.23 (C-20); 39.43 
(C-12); 38.06 (C-8); 32.59 (C-1); 28.30 (C-16); 25.51 (C-2); 25.22 (C-4); 24.01 (C-15); 21.21 (C-11); 20.17 (C-21); 12.63 (C-19); $12.30(\mathrm{C}-18) .{ }^{19} \mathrm{~F}-\mathrm{NMR}\left(470.62 \mathrm{MHz}, \mathrm{CDCl}_{3}\right) \delta(\mathrm{ppm})=$ 108.90 (s, 1F). HRMS (API+) (Figure S16, Supplementary Materials): $m / z$ calculated for $\mathrm{C}_{30} \mathrm{H}_{40} \mathrm{O}_{3} \mathrm{~F}\left([\mathrm{M}+\mathrm{H}]^{+}\right)$467.2961; found 467.2962.

(22R)-22,23-Dihydroxy-6-oxo-24-nor-5 $\alpha$-cholan-3 $\alpha$-yl 4-methylbenzoate (18a) and (22S)-22,23-dihydroxy-6-oxo-24-nor-5 $\alpha$-cholan-3 $\alpha$-yl 4-methylbenzoate (18b)

To a mixture of $t$-butanol/water $(10 \mathrm{~mL}, 1: 1 \mathrm{v} / \mathrm{v})$ and alkene $29(100 \mathrm{mg}, 0.22 \mathrm{mmol})$, DHQD-CLB (20.1 mg; $0.043 \mathrm{mmol}), \mathrm{CH}_{3} \mathrm{SO}_{2} \mathrm{NH}_{2}$ (41.12 mg; $0.43 \mathrm{mmol}$ ), $\mathrm{K}_{2} \mathrm{CO}_{3}(179.2 \mathrm{mg}$; $1.3 \mathrm{mmol})$, and $\mathrm{K}_{3}\left[\mathrm{Fe}(\mathrm{CN})_{6}\right](427.0 \mathrm{mg} ; 1.3 \mathrm{mmol})$ were added; then, the mixture was homogenized by magnetic stirring for $10 \mathrm{~min}$. Later, $100 \mu \mathrm{L}$ of $\mathrm{OsO}_{4}$ solution $(1.0 \mathrm{~g}$, $0.562 \mathrm{mmol}$ in $20 \mathrm{~mL}$ of $t$-butanol) were added, and the mixture reaction was stirred at room temperature for $5 \mathrm{~h}$. The end of the reaction was verified by TLC; then, $\mathrm{H}_{2} \mathrm{O}(10 \mathrm{~mL})$ and a saturated solution of $\mathrm{Na}_{2} \mathrm{~S}_{2} \mathrm{O}_{3} \cdot 5 \mathrm{H}_{2} \mathrm{O}(2 \mathrm{~mL})$ were added. The mixture was stirred for another $20 \mathrm{~min}$. Later, it was extracted with EtOAc $(2 \times 35 \mathrm{~mL})$ and washed with water $(2 \times 35 \mathrm{~mL})$, and both organic phases were combined, dried over $\mathrm{MgSO}_{4}$, and filtered. The solvent was evaporated under reduced pressure. The crude was re-dissolved in $\mathrm{CH}_{2} \mathrm{Cl}_{2}$ $(1.0 \mathrm{~mL})$ and chromatographed on silica gel with EtOAc/cyclohexane (16:4) mixture. A mixture of $\mathbf{1 8 a} / \mathbf{1 8 b}=1.0 / 1.0$ was obtained ( $93 \mathbf{m g} ; 91.6 \%$ yield). Separation by HPLC of an analytical sample allowed the separation and obtaining of the pure compounds 18a and $\mathbf{1 8 b}$.

Compound 18a was obtained as a colorless solid, m.p. $=74.1 \pm 4.6^{\circ} \mathrm{C} .{ }^{1} \mathrm{H}-\mathrm{NMR}(500.16$ $\left.\mathrm{MHz}, \mathrm{CDCl}_{3}\right)$ (Figure S10, Supplementary Materials): $\delta(\mathrm{ppm})=7.90(2 \mathrm{H}, \mathrm{d}, J=8.3 \mathrm{~Hz}$, HAr-2'); $7.24\left(2 \mathrm{H}, \mathrm{d}, J=8.3 \mathrm{~Hz}, \mathrm{HAr}-3^{\prime}\right) ; 5.36-5.34(1 \mathrm{H}, \mathrm{m}, \mathrm{H}-3) ; 3.80(1 \mathrm{H}, \mathrm{ddd}, J=8.9,3.3$, and $1.2 \mathrm{~Hz}, \mathrm{H}-23 \mathrm{a}) ; 3.66-3.61(1 \mathrm{H}, \mathrm{m}, \mathrm{H}-22) ; 3.52(1 \mathrm{H}, \mathrm{dd}, J=10.8$ and $3.3 \mathrm{~Hz}, \mathrm{H}-23 \mathrm{~b}) ; 2.66$ $(1 \mathrm{H}, \mathrm{dd}, J=12.5$ and $3.1 \mathrm{~Hz}, \mathrm{H}-5) ; 2.41\left(3 \mathrm{H}, \mathrm{s}, \mathrm{CH}_{3}-\mathrm{Ar}\right) ; 2.32(1 \mathrm{H}, \mathrm{dd}, J=13.1$ and $4.6 \mathrm{~Hz}$, $\mathrm{H}-7 \alpha) ; 0.921$ (3H, d, $J=6.7 \mathrm{~Hz}, \mathrm{H}-21) ; 0.783$ (3H, s, H-19); 0.681 (3H, s, H-18). ${ }^{13} \mathrm{C}-\mathrm{NMR}$ $\left(125.77 \mathrm{MHz}, \mathrm{CDCl}_{3}\right)$ (Figure S10, Supplementary Materials): $\delta(\mathrm{ppm})=211.91(\mathrm{C}-6) ; 165.82$ $\left(\mathrm{CO}_{2}-\mathrm{Ar}\right) ; 143.65$ (C4'-Ar); 129.61 (C2'-Ar, $\left.\mathrm{C6}^{\prime}-\mathrm{Ar}\right) ; 129.20$ (C3'-Ar, $\left.\mathrm{C}^{\prime}-\mathrm{Ar}\right) ; 128.15$ (C1'-Ar); 74.14 (C-22); 69.36 (C-3); 66.16 (C-23); 56.71 (C-14); 53.96 (C-17); 53.00 (C-9); 52.47 (C-5); 46.79 (C-7); 42.94 (C-13); 41.46 (C-10); 39.53 (C-20); 38.09 (C-12); 37.97 (C-8); 32.78 (C-1); 27.72 (C-16); 25.55 (C-2); 25.24 (C-4); 23.95 (C-15); $21.78\left(\mathrm{CH}_{3}-\mathrm{Ar}\right) ; 21.22$ (C-11); 12.73 (C-21); 12.55 (C-19); 12.00 (C-18). HRMS (API+) (Figure S17, Supplementary Materials): calculated for $\mathrm{C}_{31} \mathrm{H}_{45} \mathrm{O}_{5}\left([\mathrm{M}+\mathrm{H}]^{+}\right)$497.3267, found 497.3262.

Compound $18 \mathrm{~b}$ was obtained as a colorless solid, m.p. $=83.0 \pm 5.0{ }^{\circ} \mathrm{C} .{ }^{1} \mathrm{H}-\mathrm{NMR}$ $\left(500.16 \mathrm{MHz}, \mathrm{CDCl}_{3}\right)$ (Figure S11, Supplementary Materials): $\delta(\mathrm{ppm})=7.89(2 \mathrm{H}, \mathrm{d}$, $\left.J=8.2 \mathrm{~Hz}, \mathrm{HAr}-2^{\prime}\right) ; 7.23\left(2 \mathrm{H}, \mathrm{d}, J=8.2 \mathrm{~Hz}, \mathrm{HAr}-3^{\prime}\right) ; 5.36-5.34(1 \mathrm{H}, \mathrm{m}, \mathrm{H}-3) ; 3.83-3.76(1 \mathrm{H}$, $\mathrm{m}, \mathrm{H}-23 \mathrm{a}) ; 3.69-3.57(1 \mathrm{H}, \mathrm{m}, \mathrm{H}-23 \mathrm{~b}) ; 3.51(1 \mathrm{H}, \mathrm{t}, J=10.2 \mathrm{~Hz}, \mathrm{H}-22) ; 2.65(1 \mathrm{H}, \mathrm{dd}, J=12.5$ and $3.1 \mathrm{~Hz}, \mathrm{H}-5) ; 2.41\left(3 \mathrm{H}, \mathrm{s}, \mathrm{CH}_{3}-\mathrm{Ar}\right) ; 2.32(1 \mathrm{H}, \mathrm{dd}, J=13.1$ and $4.6 \mathrm{~Hz}, \mathrm{H}-7 \alpha) ; 0.953(3 \mathrm{H}$, $\mathrm{d}, J=7.0 \mathrm{~Hz}, \mathrm{H}-21) ; 0.778$ (3H, s, H-19); 0.679 (3H, s, H-18). ${ }^{13} \mathrm{C}-\mathrm{NMR}\left(125.77 \mathrm{MHz}, \mathrm{CDCl}_{3}\right.$ ) (Figure S11, Supplementary Materials): $\delta(\mathrm{ppm})=211.82(\mathrm{C}-6) ; 165.79\left(\mathrm{CO}_{2}-\mathrm{Ar}\right) ; 143.65$ (C4'-Ar); 129.60 (C2'-Ar and $\left.\mathrm{C}^{\prime}{ }^{\prime}-\mathrm{Ar}\right) ; 129.18$ (C3'-Ar and $\left.\mathrm{C}^{\prime}{ }^{\prime}-\mathrm{Ar}\right) ; 128.16\left(\mathrm{C}^{\prime}{ }^{\prime}-\mathrm{Ar}\right) ; 73.92$ (C-22); 69.36 (C-3); 62.54 (C-23); 56.42 (C-14); 54.06 (C-17); 53.02 (C-9); 52.92 (C-5); 46.79 (C-7); 43.48 (C-13); 41.43 (C-10); 40.15 (C-20); 39.47 (C-12); 38.04 (C-8); 32.81 (C-1); 27.47 (C-16); 25.55 (C-2); 25.23 (C-4); 24.12 (C-15); $21.78\left(\mathrm{CH}_{3}-\mathrm{Ar}\right) ; 21.21$ (C-11); 13.15 (C-21); 12.55 (C-19); 11.85 (C-18). HRMS (API+) (Figure S18, Supplementary Materials): calculated for $\mathrm{C}_{31} \mathrm{H}_{45} \mathrm{O}_{5}\left([\mathrm{M}+\mathrm{H}]^{+}\right)$497.3267, found 497.3265.

(22R)-22,23-Dihydroxy-6-oxo-24-nor-5 $\alpha$-cholan-3 $\alpha$-yl 2-fluorobenzoate (19a) and (22S)-22,23-dihydroxy-6-oxo-24-nor-5 $\alpha$-cholan-3 $\alpha$-yl 2-fluorobenzoate (19b)

To a mixture of $t$-butanol/water ( $8 \mathrm{~mL} ; 1: 1 v / v)$, alkene 29 (75 mg; $0.161 \mathrm{mmol})$, DHQDCLB (15.9 mg; $0.0343 \mathrm{mmol}), \mathrm{CH}_{3} \mathrm{SO}_{2} \mathrm{NH}_{2}$ (32.61 mg; $0.343 \mathrm{mmol}$ ), $\mathrm{K}_{2} \mathrm{CO}_{3}$ (142.2 mg; $1.03 \mathrm{mmol})$, and $\mathrm{K}_{3}\left[\mathrm{Fe}(\mathrm{CN})_{6}\right](338,7 \mathrm{mg} ; 1,03 \mathrm{mmol})$ were added; then, the mixture was homogenized by magnetic stirring for $10 \mathrm{~min}$. Later, $100 \mu \mathrm{L}$ of $\mathrm{OsO}_{4}$ solution $(1.0 \mathrm{~g}$, $0.562 \mathrm{mmol}$ in $20 \mathrm{~mL}$ of $t$-butanol) were added, and the mixture reaction was stirred at 
room temperature for $5 \mathrm{~h}$. The end of the reaction was verified by TLC; then, $\mathrm{H}_{2} \mathrm{O}(10 \mathrm{~mL})$ and a saturated solution of $\mathrm{Na}_{2} \mathrm{~S}_{2} \mathrm{O}_{3} \cdot 5 \mathrm{H}_{2} \mathrm{O}(2 \mathrm{~mL})$ were added. The mixture was stirred for another $20 \mathrm{~min}$. Later, it was extracted with EtOAc $(2 \times 35 \mathrm{~mL})$ and washed with water $(2 \times 35 \mathrm{~mL})$, and both organic phases were combined, dried over $\mathrm{MgSO}_{4}$, and filtered. The solvent was evaporated under reduced pressure. The crude was re-dissolved in $\mathrm{CH}_{2} \mathrm{Cl}_{2}$ $(1.0 \mathrm{~mL})$ and chromatographed on silica gel with an EtOAc/cyclohexane (16:4) mixture. A mixture of $19 a / 19 b=1.0 / 1.0$ was obtained ( $65 \mathrm{mg}: 80.8 \%$ yield). The separation by HPLC of an analytical sample allowed the separation and obtaining of the pure compounds 19a and $19 b$.

Compound 19a was obtained as a colorless solid, m.p. $=56.9 \pm 4.6{ }^{\circ} \mathrm{C} .{ }^{1} \mathrm{H}-\mathrm{NMR}$ $\left(500.16 \mathrm{MHz} \mathrm{CDCl}_{3}\right)$ (Figure S12, Supplementary Materials): $\delta(\mathrm{ppm})=7.92(1 \mathrm{H}, \mathrm{td}, J=7.6$ and $\left.1.8 \mathrm{~Hz}, \mathrm{HAr}-6^{\prime}\right) ; 7.56-7.48\left(1 \mathrm{H}, \mathrm{m}, \mathrm{HAr}-4^{\prime}\right) ; 7.21\left(1 \mathrm{H}, \mathrm{td}, J=7.6\right.$ and $\left.1.2 \mathrm{~Hz}, \mathrm{HAr}-3^{\prime}\right) ; 7.13$ $\left(1 \mathrm{H}, \mathrm{ddd}, J=10.7,7.6\right.$ and $\left.0.9 \mathrm{~Hz}, \mathrm{HAr}-5^{\prime}\right) ; 5.40-5.39(1 \mathrm{H}, \mathrm{m}, \mathrm{H}-3) ; 3.87-3.76(1 \mathrm{H}, \mathrm{m}, \mathrm{H}-23 \mathrm{a})$; 3.75-3.39 (2H, m, H-22, H-23b); $2.71(1 \mathrm{H}, \mathrm{dd}, J=12.5$ and $3.1 \mathrm{~Hz}, \mathrm{H}-5) ; 2.31(1 \mathrm{H}, \mathrm{dd}, J=13.1$ and $4.6 \mathrm{~Hz}, \mathrm{H}-7 \alpha) ; 0.917(3 \mathrm{H}, \mathrm{d}, J=6.4 \mathrm{~Hz}, \mathrm{H}-21) ; 0.776(3 \mathrm{H}, \mathrm{s}, \mathrm{H}-19) ; 0.676(3 \mathrm{H}, \mathrm{s}, \mathrm{H}-18)$. ${ }^{13} \mathrm{C}-\mathrm{NMR}\left(125.77 \mathrm{MHz}, \mathrm{CDCl}_{3}\right)$ (Figure S12, Supplementary Materials): $\delta(\mathrm{ppm})=212.12$ (C-6); $163.89\left(\mathrm{~d},{ }^{3} J_{\mathrm{CF}}=3,6 \mathrm{~Hz}, \mathrm{CO}_{2}-\mathrm{Ar}\right) ; 161.93\left(\mathrm{~d},{ }^{1} J_{\mathrm{CF}}=259.1 \mathrm{~Hz}, \mathrm{C} 2^{\prime}-\mathrm{Ar}\right) ; 134.49$ (d, $\left.{ }^{3} J_{\mathrm{CF}}=8.4 \mathrm{~Hz}, \mathrm{C} 4^{\prime}-\mathrm{Ar}\right) ; 132.31\left(\mathrm{~d},{ }^{3} J_{\mathrm{CF}}=0.9 \mathrm{~Hz}, \mathrm{C} 6^{\prime}-\mathrm{Ar}\right) ; 124.13\left(\mathrm{~d},{ }^{4} J_{\mathrm{CF}}=3.6 \mathrm{~Hz}, \mathrm{C} 5^{\prime}-\mathrm{Ar}\right)$; $117.17\left(\mathrm{~d},{ }^{2} J_{\mathrm{CF}}=9.6 \mathrm{~Hz}, \mathrm{Cl}^{\prime}-\mathrm{Ar}\right) ; 116.99\left(\mathrm{~d},{ }^{2} J_{\mathrm{CF}}=21.6 \mathrm{~Hz}, \mathrm{C}^{\prime}-\mathrm{Ar}\right) ; 75.56(\mathrm{C}-22) ; 70.33(\mathrm{C}-3)$; 61.15 (C-23); 56.67 (C-14); 53.85 (C-17); 52.79 (C-9); 52.45 (C-5); 46.78 (C-7); 43.47 (C-13); 42.93 (C-10); 41.41 (C-20); 39.51 (C-12); 38.09 (C-8); 32.55 (C-1); 27.72 (C-16); 25.49 (C-2); 25.20 (C-4); 23.94 (C-15); 21.21 (C-11); 12.73 (C-21); 12.61 (C-19); 12.00 (C-18). ${ }^{19}$ F-NMR $\left(470.62 \mathrm{MHz}, \mathrm{CDCl}_{3}\right) \delta(\mathrm{ppm})=-108,91(\mathrm{~s}, 1 \mathrm{~F})$. HRMS (API+) (Figure S19, Supplementary Materials): calculated for $\mathrm{C}_{30} \mathrm{H}_{42} \mathrm{O}_{5} \mathrm{~F}\left([\mathrm{M}+\mathrm{H}]^{+}\right)$501.3016, found 501.3015.

Compound 19b was obtained as a colorless solid, m.p. $=75.4 \pm 1.5{ }^{\circ} \mathrm{C} .{ }^{1} \mathrm{H}-\mathrm{NMR}$ $\left(500.16 \mathrm{MHz} \mathrm{CDCl}_{3}\right)$ (Figure S13, Supplementary Materials): $\delta(\mathrm{ppm})=7.92(1 \mathrm{H}, \mathrm{td}, J=7.6$ and $\left.1.8 \mathrm{~Hz}, \mathrm{HAr}-6^{\prime}\right) ; 7.54-7.49\left(1 \mathrm{H}, \mathrm{m}, \mathrm{HAr}-4^{\prime}\right) ; 7.21\left(1 \mathrm{H}, \mathrm{td}, J=7.6\right.$ and $\left.1.2 \mathrm{~Hz}, \mathrm{HAr}-3^{\prime}\right) ; 7.13$ $\left.\left(1 \mathrm{H}, \mathrm{ddd}, J=10.7,7.6 \text {, and } 0.9 \mathrm{~Hz}, \mathrm{HAr}^{\prime}\right)^{\prime}\right) ; 5.40-5.39(1 \mathrm{H}, \mathrm{m}, \mathrm{H}-3) ; 3.84-3.76(1 \mathrm{H}, \mathrm{m}, \mathrm{H}-23 \mathrm{a})$; 3.71-3.69 (1H, m, H-23b); $3.51(1 \mathrm{H}, \mathrm{t}, J=10.2 \mathrm{~Hz}, \mathrm{H}-22) ; 2.70(1 \mathrm{H}, \mathrm{dd}, J=12.5$ and $3.1 \mathrm{~Hz}$, $\mathrm{H}-5) ; 2.31(1 \mathrm{H}, \mathrm{dd}, J=13.1$ and $4.6 \mathrm{~Hz}, \mathrm{H}-7 \alpha) ; 0.954(3 \mathrm{H}, \mathrm{d}, J=6.7 \mathrm{~Hz}, \mathrm{H}-21) ; 0.777(3 \mathrm{H}$, s, H-19); 0.681 (3H, s, H-18). ${ }^{13} \mathrm{C}-\mathrm{NMR}\left(125.77 \mathrm{MHz}^{\mathrm{CDCl}}{ }_{3}\right.$ ) (Figure S13, Supplementary Materials): $\delta(\mathrm{ppm})=211.97(\mathrm{C}-6) ; 163.89\left(\mathrm{~d},{ }^{3} J_{\mathrm{CF}}=3.6 \mathrm{~Hz}, \mathrm{CO}_{2}-\mathrm{Ar}\right) ; 160.87\left(\mathrm{~d},{ }^{1} J_{\mathrm{CF}}=\right.$ $\left.259.1 \mathrm{~Hz}, \mathrm{C} 2^{\prime}-\mathrm{Ar}\right) ; 134.48\left(\mathrm{~d},{ }^{3} J_{\mathrm{CF}}=8.4 \mathrm{~Hz}, \mathrm{C} 4^{\prime}-\mathrm{Ar}\right) ; 132.34\left(\mathrm{~d},{ }^{3} J_{\mathrm{CF}}=0.9 \mathrm{~Hz}, \mathrm{C} 6^{\prime}-\mathrm{Ar}\right) ; 124.13$ $\left(\mathrm{d},{ }^{4} J_{\mathrm{CF}}=3.6 \mathrm{~Hz}, \mathrm{C} 5^{\prime}-\mathrm{Ar}\right) ; 118.37\left(\mathrm{~d},{ }^{2} J_{\mathrm{CF}}=9.6 \mathrm{~Hz}, \mathrm{C} 1^{\prime}-\mathrm{Ar}\right) ; 117.04\left(\mathrm{~d},{ }^{2} J_{\mathrm{CF}}=21.6 \mathrm{~Hz}\right.$, C3'-Ar); 73.90 (C-22); 70.32 (C-3); 62.52 (C-23); 56.37 (C-14); 53.95 (C-17); 52.90 (C-9); 52.79 (C-5); 46.78 (C-7); 43.48 (C-13); 41.38 (C-10); 40.15 (C-20); 39.46 (C-12); 38.04 (C-8); 32.57 (C-1); 27.47 (C-16); 25.48 (C-2); 25.20 (C-4); 24.11 (C-15); 21.19 (C-11); 13.13 (C-21); 12.62 (C-19); 11.85 (C-18). ${ }^{19}$ F-NMR (470.62 MHz, CDCl 3 ) $\delta(\mathrm{ppm})=-108,90$ (s, 1F). HRMS (API+) (Figure S20, Supplementary Materials): calculated for $\mathrm{C}_{30} \mathrm{H}_{42} \mathrm{O}_{5} \mathrm{~F}\left([\mathrm{M}+\mathrm{H}]^{+}\right)$501.3016, found 501.3014 .

\subsection{Biological}

Rice Lamina Inclination Test (RLIT)

The biological activity of the growth of the compounds was evaluated by the rice lamina inclination test $[55,56]$, according to a previously described procedure [38], and using the same a Zafiro cultivar (Oryza sativa) provided by the Institute of Agricultural Research (INIA-Quilamapu-Chile) as previous studies.

The seeds were sown and cultivated until the seedlings presenting the second internode of the rice blade were selected for cutting. Six segments per treatment were incubated in Petri dishes containing $60 \mathrm{~mL}$ of distilled water, and the amount of test compound (BRs analogs 18a, 18b, 19a, 19b, 20a, and 20b and positive control (1)) needed to reach final concentrations equal to $1 \times 10^{-8} \mathrm{M} ; 1 \times 10^{-7} \mathrm{M}$; and $1 \times 10^{-6} \mathrm{M}$. The negative control only contained sterile distilled water. All treatments were incubated by $48 \mathrm{~h}$ at $25^{\circ} \mathrm{C}$ in 
darkness, and the angles developed between the blade and the sheath were measured. Each experiment was performed by duplicate.

Results were expressed as mean \pm standard deviation (SD) using twelve angle measurements. Statistical analysis was done using a statistical package Excel by applying mean values using one-way ANOVA with the post-hoc least square differences (LSD) test to determine if there was a significant difference between the positive control and the treatments. A $P$ value of less than 0.05 was considered significant.

\section{Conclusions}

Brassinosteroid 24-norcholane type analogs conjugated at C-3 and configurations $S$ and $R$ on the C-22 carbon of the side chain have been synthesized and characterized. The synthesis uses hyodeoxycholic acid as the starting material, and epimers with different configuration at C-22 are obtained. These epimers have been separated, and their growthpromoting activity was measured using RLIT. The results show that the esterification of BRs analog at C-3 has no effect on the biological activity of synthetic analogs. This suggest that reducing activity by esterification at $\mathrm{C}-3$ requires a long chain carboxylic acid. In addition, the presence of a hydroxyl group at $\mathrm{C}-3$ is not an essential structural feature for activity. This result confirms previous SAR where it has been proposed that activity is not determined by the presence or absence of specific groups in the BR structure.

Supplementary Materials: The following are available online, Figure S1: NMR spectra of $3 \alpha, 6 \alpha-$ diacetoxy-5 $\beta$-cholan-24-oic acid (22), Figure S2: NMR spectra of 24-nor-5 5 -cholan-22-ene-3 $\alpha, 6 \alpha-$ diyl diacetate (23), Figure S3: NMR spectra of 24-nor-5 $\beta$-chol-22-ene- $3 \alpha, 6 \alpha-$ diol (24), Figure S4: NMR spectra of $6 \alpha$-hydroxy-24-nor-5 $\beta$-chol-22-en-3-one (25), Figure S5: NMR spectra of 24-nor$5 \beta$-chol-22-ene-3,6-dione (26), Figure S6: NMR spectra of $3 \alpha$-hydroxy-24-nor-5 $\beta$-chol-22-en-6-one (27), Figure S7: NMR spectra of $3 \alpha$-hydroxy-24-nor-5 $\beta$-chol-22-en-6-one (28), Figure S8: NMR spectra of 6-oxo-24-nor-5 $\beta$-chol-22-en-3 $\alpha$-yl 4-methylbenzoate (29), Figure S9: NMR spectra of 6-oxo-24-nor-5 $\beta$-chol-22-en-3 $\alpha$-yl 2-fluorobenzoate (30), Figure S10: NMR spectra of (22R)-22,23dihydroxy-6-oxo-24-nor-5 $\beta$-cholan-3 $\alpha$-yl 4-methylbenzoate (18a), Figure S11: NMR spectra of (22S)22,23-dihydroxy-6-oxo-24-nor-5 $\beta$-cholan-3 $\alpha$-yl 4-methylbenzoate (18b), Figure S12: NMR spectra of (22R)-22,23-dihydroxy-6-oxo-24-nor-5 $\beta$-cholan-3 $\alpha$-yl 2-fluorobenzoate (19a), Figure S13: NMR spectra of (22S)-22,23-dihydroxy-6-oxo-24-nor-5 $\beta$-cholan-3 $\alpha$-yl 2-fluorobenzoate (19b), Figure S14: HRMS (API ${ }^{+}$) spectrum of $3 \alpha$-hydroxy-24-nor-5 3 -chol-22-en-6-one (28), Figure S15: HRMS (API ${ }^{+}$) spectrum of 6-oxo-24-nor-5 $\beta$-chol-22-en-3 $\alpha$-yl 4-methylbenzoate (29), Figure S16: HRMS (API ${ }^{+}$) spectrum of 6-oxo-24-nor-5 $\beta$-chol-22-en-3 $\alpha$-yl 2-fluorobenzoate (30), Figure S17: HRMS (API ${ }^{+}$) spectrum of (22R)-22,23-dihydroxy-6-oxo-24-nor-5 $\beta$-cholan-3 $\alpha$-yl 4-methylbenzoate (18a), Figure S18: HRMS $\left(\mathrm{API}^{+}\right.$) spectrum of (22S)-22,23-dihydroxy-6-oxo-24-nor-5 $\beta$-cholan-3 $\alpha$-yl 4-methylbenzoate (18b), Figure S19: HRMS $\left(\mathrm{API}^{+}\right)$spectrum of (22R)-22,23-dihydroxy-6-oxo-24-nor-5 $\beta$-cholan-3 $\alpha$-yl 2-fluorobenzoate (19a), Figure S20: HRMS $\left(\mathrm{API}^{+}\right)$spectrum of (22S)-22,23-dihydroxy-6-oxo-24-nor$5 \beta$-cholan-3 $\alpha$-yl 2-fluorobenzoate (19b).

Author Contributions: Conceptualization, L.E., K.F. and K.D.; methodology, L.E., M.K., K.D. and K.F.; validation, L.E., M.K., K.D. and K.F.; formal analysis, L.E., M.K., K.D., K.F., A.F.O. and M.C.; investigation, L.E., M.K., K.D. and K.F.; resources, L.E., M.K., K.D. and K.F.; writing—original draft preparation, L.E. and K.D.; writing—review and editing, A.F.O., and M.K.; supervision, L.E., M.K. and K.D.; project administration, L.E.; funding acquisition, L.E. All authors have read and agreed to the published version of the manuscript.

Funding: This research was funded by FONDECYT (Fondo Nacional de Desarrollo Científico y Tecnológico) (grant No. 1191330). This work was partially funded by ERDF (European Regional Development Fund) project "Plants as a tool for sustainable global development" (No. CZ.02.1.01/0.0/0.0/16_019/0000827).

Data Availability Statement: The data presented in this study are available in Supplementary Material.

Acknowledgments: Karoll Ferrer wants to thank the Agencia Nacional de Investigación y Desarrollo ANID (Nacional Doctoral Fellowship No. 21170877), the Dirección General de Investigación Innovación y Emprendimiento (DGIIE-USM), the Dirección de Postgrado y Programas de la Univer- 
sidad Técnica Federico Santa María and Miroslav Kvasnica, Ph.D. Laboratory of Growth Regulators, Institute of Experimental Botany \& Palacký University, Olomouc, Czech Republic.

Conflicts of Interest: The authors declare no conflict of interest.

\section{References}

1. Oh, M.-H.; Honey, S.H.; Tax, F.E. The Control of Cell Expansion, Cell Division, and Vascular Development by Brassinosteroids: A Historical Perspective. Int. J. Mol. Sci. 2020, 21, 1743. [CrossRef]

2. Clouse, S.D.; Sasse, J.M. Brassinosteroids: Essential regulators of plant growth and development. Annu. Rev. Plant Physiol. Plant Mol. Biol. 1998, 49, 427-451. [CrossRef]

3. Yokota, T. Chapter 12-Brassinosteroids. In New Comprehensive Biochemistry; Hooykaas, P.J.J., Hall, M.A., Libbenga, K.R., Eds.; Elsevier: New York, NY, USA, 1999; Volume 33, p. 277293.

4. Sasse, J.M. Physiological actions of brassinosteroids: An update. J. Plant Growth Regul. 2003, 22, 276-288. [CrossRef]

5. Müssig, C. Brassinosteroid-promoted growth. Plant Biol. 2005, 7, 110-117. [CrossRef]

6. Grove, M.D.; Spencer, G.F.; Rohwedder, W.K.; Mandava, N.; Worley, J.F.; Warthen, J.D.; Steffens, G.L.; Flippenanderson, J.L.; Cook, J.C. Brassinolide, a Plant Growth-Promoting Steroid Isolated from Brassica-Napus Pollen. Nature 1979, 281, 216-217. [CrossRef]

7. Khripach, V.; Zhabinskii, V.; de Groot, A. Twenty years of brassinosteroids: Steroidal plant hormones warrant better crops for the XXI century. Ann. Bot. 2000, 86, 441-447. [CrossRef]

8. Bajguz, A. Metabolism of brassinosteroids in plants. Plant Physiol. Biochem. 2007, 45, 95-107. [CrossRef]

9. Abe, H.; Honjo, C.; Kyokawa, Y.; Asakawa, S.; Natsume, M.; Narushima, M. 3-Oxoteasterone and the Epimerization of Teasterone: Identification in Lily Anthers and Distylium racemosum Leaves and Its Biotransformation into Typhasterol. Biosci. Biotechnol. Biochem. 1994, 58, 986-989. [CrossRef]

10. Kolbe, A.; Schneider, B.; Porzel, A.; Adam, G. Metabolism of 24-epi-castasterone and 24-epi-brassinolide in cell suspension cultures of Ornithopus sativus. Phytochemistry 1996, 41, 163-167. [CrossRef]

11. Kolbe, A.; Schneider, B.; Porzel, A.; Schmidt, J.; Adam, G. Acyl-conjugated metabolites of brassinosteroids in cell suspension cultures of Ornithopus sativus. Phytochemistry 1995, 38, 633-636. [CrossRef]

12. Kolbe, A.; Schneider, B.; Porzel, A.; Voigt, B.; Krauss, G.; Adam, G. Pregnane-type metabolites of brassinosteroids in cell suspension cultures of Ornithopus sativus. Phytochemistry 1994, 36, 671-673. [CrossRef]

13. Soeno, K.; Asakawa, S.; Natsume, M.; Abe, H. Reversible Conversion between Teasterone and Its Ester Conjugates in Lily Cell Cultures. J. Pestic. Sci. 2000, 25, 117-122. [CrossRef]

14. Soeno, K.; Kyokawa, Y.; Natsume, M.; Abe, H. Teasterone-3-O- $\beta$-D-glucopyranoside, A New Conjugated Brassinosteroid Metabolite from Lily Cell Suspension Cultures and Its Identification in Lily Anthers. Biosci. Biotechnol. Biochem. 2000, 64, 702-709. [CrossRef]

15. Hai, T.; Schneider, B.; Adam, G. Metabolic conversion of 24-epi-brassinolide into pentahydroxylated brassinosteroid glucosides in tomato cell cultures. Phytochemistry 1995, 40, 443-448. [CrossRef]

16. Hai, T.; Schneider, B.; Porzel, A.; Adam, G. Metabolism of 24-epi-castasterone in cell suspension cultures of Lycopersicon esculentum. Phytochemistry 1996, 41, 197-201. [CrossRef]

17. Kolbe, A.; Porzel, A.; Schneider, B.; Adam, G. Diglycosidic metabolites of 24-epi-teasterone in cell suspension cultures of Lycopersicon esculentum L. Phytochemistry 1997, 46, 1019-1022. [CrossRef]

18. Kolbe, A.; Schneider, B.; Porzel, A.; Adam, G. Metabolic inversion of the 3-hydroxy function of brassinosteroids. Phytochemistry 1998, 48, 467-470. [CrossRef]

19. Schneider, B.; Kolbe, A.; Porzel, A.; Adam, G. A metabolite of 24-epi-brassinolide in cell suspension cultures of Lycopersicon esculentum. Phytochemistry 1994, 36, 319-321. [CrossRef]

20. Suzuki, H.; Kim, S.-K.; Takahashi, N.; Yokota, T. Metabolism of castasterone and brassinolide in mung bean explant. Phytochemistry 1993, 33, 1361-1367. [CrossRef]

21. Khripach, V.A.; Zhabinskii, V.N.; Tsavlovskii, D.V. Synthesis of fatty acyl derivatives of 24-epibrassinolide. J. Steroid Biochem. Mol. Biol. 2013, 137, 345-354. [CrossRef]

22. Kvasnica, M.; Oklestkova, J.; Bazgier, V.; Rarova, L.; Berka, K.; Strnad, M. Biological activities of new monohydroxylated brassinosteroid analogues with a carboxylic group in the side chain. Steroids 2014, 85, 58-64. [CrossRef]

23. Liu, J.; Zhang, D.; Sun, X.; Ding, T.; Lei, B.; Zhang, C. Structure-activity relationship of brassinosteroids and their agricultural practical usages. Steroids 2017, 124, 1-17. [CrossRef]

24. Thompson, M.J.; Meudt, W.J.; Mandava, N.B.; Dutky, S.R.; Lusby, W.R.; Spaulding, D.W. Synthesis of Brassinosteroids and Relationship of Structure to Plant Growth-Promoting Effects. Steroids 1982, 39, 89-105. [CrossRef]

25. Takatsuto, S.; Ikekawa, N.; Morishita, T.; Abe, H. Structure Activity Relationship of Brassinosteroids with Respect to the A/B-Ring Functional-Groups. Chem. Pharm. Bull. 1987, 35, 211-216. [CrossRef]

26. Takatsuto, S.; Yazawa, N.; Ikekawa, N.; Takematsu, T.; Takeuchi, Y.; Koguchi, M. Structure Activity Relationship of Brassinosteroids. Phytochemistry 1983, 22, 2437-2441. [CrossRef]

27. Zullo, M.A.T.; Adam, G. Brassinosteroid phytohormones: Structure, bioactivity and applications. Braz. J. Plant Physiol. 2002, 14, 143-181. [CrossRef] 
28. Peres, A.L.G.L.; Soares, J.S.; Tavares, R.G.; Righetto, G.; Zullo, M.A.T.; Mandava, N.B.; Menossi, M. Brassinosteroids, the Sixth Class of Phytohormones: A Molecular View from the Discovery to Hormonal Interactions in Plant Development and Stress Adaptation. Int. J. Mol. Sci. 2019, 20, 331. [CrossRef]

29. Ferrer-Pertuz, K.; Espinoza, L.; Mella, J. Insights into the Structural Requirements of Potent Brassinosteroids as Vegetable Growth Promoters Using Second-Internode Elongation as Biological Activity: CoMFA and CoMSIA Studies. Int. J. Mol. Sci. 2017, 18, 2734. [CrossRef]

30. Wang, Q.; Xu, J.; Liu, X.; Gong, W.; Zhang, C. Synthesis of brassinosteroids analogues from laxogenin and their plant growth promotion. Nat. Prod. Res. 2015, 29, 149-157. [CrossRef]

31. Duran, M.I.; Gonzalez, C.; Acosta, A.; Olea, A.F.; Diaz, K.; Espinoza, L. Synthesis of Five Known Brassinosteroid Analogs from Hyodeoxycholic Acid and Their Activities as Plant-Growth Regulators. Int. J. Mol. Sci. 2017, 18, 516. [CrossRef]

32. Kvasnica, M.; Oklestkova, J.; Bazgier, V.; Rárová, L.; Korinkova, P.; Mikulík, J.; Budesinsky, M.; Béres, T.; Berka, K.; Lu, Q.; et al. Design, synthesis and biological activities of new brassinosteroid analogues with a phenyl group in the side chain. Org. Biomol. Chem. 2016, 14, 8691-8701. [CrossRef]

33. Iglesias-Arteaga, M.A.; Gil, R.P.; Martinez, C.S.P.; Manchado, F.C. Spirostanic analogues of teasterone. Synthesis, characterisation and biological activity of laxogenin, (23S)-hydroxylaxogenin and 23-ketolaxogenin (23-oxolaxogenin). J. Chem. Soc. Perkin Trans. 1 2001, 261-266. [CrossRef]

34. Romero-Avila, M.; de Dios-Bravo, G.; Mendez-Stivalet, J.M.; Rodriguez-Sotres, R.; Iglesias-Arteaga, M.A. Synthesis and biological activity of furostanic analogues of brassinosteroids bearing the 5 alpha-hydroxy-6-oxo moiety. Steroids 2007, 72, 955-959. [CrossRef]

35. Gomes, M.d.M.d.A.; Torres Netto, A.; Campostrini, E.; Bressan-Smith, R.; Zullo, M.A.T.; Ferraz, T.M.; Siqueira, L.d.N.; Leal, N.R.; Núñez-Vázquez, M. Brassinosteroid analogue affects the senescence in two papaya genotypes submitted to drought stress. Exp. Plant Physiol. 2013, 25, 186-195. [CrossRef]

36. Brosa, C.; Soca, L.; Terricabras, E.; Ferrer, J.C.; Alsina, A. New synthetic brassinosteroids: A 5 alpha-hydroxy-6-ketone analog with strong plant growth promoting activity. Tetrahedron 1998, 54, 12337-12348. [CrossRef]

37. Brosa, C.; Capdevila, J.M.; Zamora, I. Brassinosteroids: A new way to define the structural requirements. Tetrahedron 1996, 52, 2435-2448. [CrossRef]

38. Diaz, K.; Espinoza, L.; Carvajal, R.; Conde-Gonzalez, M.; Niebla, V.; Olea, A.F.; Coll, Y. Biological Activities and Molecular Docking of Brassinosteroids 24-Norcholane Type Analogs. Int. J. Mol. Sci. 2020, 21, 1832. [CrossRef]

39. Back, T.; Pharis, R. Structure-Activity Studies of Brassinosteroids and the Search for Novel Analogues and Mimetics with Improved Bioactivity. J. Plant Growth Regul. 2004, 22, 350-361. [CrossRef]

40. Back, T.G.; Janzen, L.; Pharis, R.P.; Yan, Z. Synthesis and bioactivity of C-2 and C-3 methyl ether derivatives of brassinolide. Phytochemistry 2002, 59, 627-634. [CrossRef]

41. Carvajal, R.; Gonzalez, C.; Olea, A.F.; Fuentealba, M.; Espinoza, L. Synthesis of 2-Deoxybrassinosteroids Analogs with 24-nor, 22(S)-23-Dihydroxy-Type Side Chains from Hyodeoxycholic Acid. Molecules 2018, 23, 1306. [CrossRef]

42. Oyarce, J.; Aitken, V.; Gonzalez, C.; Ferrer, K.; Olea, A.F.; Parella, T.; Espinoza, L. Synthesis and structural determination of new brassinosteroid 24-nor-5 $\alpha$-cholane type analogs. Molecules 2019, 24, 4612. [CrossRef]

43. Huang, L.F.; Zhou, W.S. Studies on Steroidal Plant-Growth Regulators. Part 33. Novel Method for Construction of the Side-Chain of 23-Arylbrassinosteroids Via Heck Arylation and Asymmetric Dihydroxylation As Key Steps. J. Chem. Soc. Perkin Trans. 1 1994, 3579-3585. [CrossRef]

44. Zhou, W.S.; Tian, W.S. Studies on Steroidal Plant-Growth Hormones. 2. Stereoselective Synthesis of (22S, 23S)-Typhasterol from Hyodeoxycholic Acid. Acta Chim. Sin. 1985, 43, 1060-1067.

45. Tian, W.S.; Zhou, W.S.; Jiang, B.; Pan, X.F. Studies on Steroidal Plant-Growth Regulator. 9. The Preparation of 22R-Penta-NorBrassinolides and 22S-24,25,26,27,28-Penta-Nor-Brassinolides. Acta Chim. Sin. 1989, 47, 1017-1021.

46. Yang, Y.X.; Zheng, L.T.; Shi, J.J.; Gao, B.; Chen, Y.K.; Yang, H.C.; Chen, H.L.; Li, Y.C.; Zhen, X.C. Synthesis of 5 alpha-cholestan-6one derivatives and their inhibitory activities of NO production in activated microglia: Discovery of a novel neuroinflammation inhibitor. Bioorg. Med. Chem. Lett. 2014, 24, 1222-1227. [CrossRef]

47. Zhou, W.S.; Tian, W.S. The Synthesis of Steroids Containing Structural Unit of A, B Ring of Brassinolide and Ecdysone from Hyodeoxycholic Acid. Acta Chim. Sin. 1984, 42, 1173-1177.

48. Zhou, W.S. The Synthesis of Brassinosteroid. Pure Appl. Chem. 1989, 61, 431-434. [CrossRef]

49. Herrera, H.; Carvajal, R.; Olea, A.F.; Espinoza, L. Structural modifications of deoxycholic acid to obtain three known brassinosteroid analogues and full NMR spectroscopic characterization. Molecules 2016, 21, 1139. [CrossRef]

50. Huang, B.; Du, D.; Zhang, R.; Wu, X.; Xing, Z.; He, Y.; Huang, W. Synthesis, characterization and biological studies of diosgenyl analogues. Bioorg Med. Chem Lett 2012, 22, 7330-7334. [CrossRef]

51. Jones, S.R.; Selinsky, B.S.; Rao, M.N.; Zhang, X.; Kinney, W.A.; Tham, F.S. Efficient Route to $7 \alpha$-(Benzoyloxy)-3-dioxolane Cholestan-24(R)-ol, a Key Intermediate in the Synthesis of Squalamine. J. Org. Chem. 1998, 63, 3786-3789. [CrossRef]

52. Li, H.; Wang, H.; Jang, S. Rice Lamina Joint Inclination Assay. Bio-Protocol. 2017, 7, e2409. [CrossRef]

53. Jang, S.; An, G.; Li, H.-Y. Rice Leaf Angle and Grain Size Are Affected by the OsBUL1 Transcriptional Activator Complex. Plant Physiol. 2017, 173, 688-702. [CrossRef] 
54. Bajguz, A.; Tretyn, A. The chemical characteristic and distribution of brassinosteroids in plants. Phytochemistry 2003, 62, 1027-1046. [CrossRef]

55. Wada, K.; Marumo, S. Synthesis and Plant Growth-Promoting Activity of Brassinolide Analogs. Agric. Biol. Chem. 1981, 45, 2579-2585.

56. Han, K.S.; Ko, K.W.; Nam, S.J.; Park, S.H.; Kim, S.K. Optimization of a rice lamina inclination assay for detection of brassinosteroids: I. effect of phytohormones on the inclination activity. J. Plant Biol. 1997, 40, 240-244. [CrossRef] 